\title{
Structural Evolution of Layered Manganese Oxysulfides during Reversible Electrochemical Lithium Insertion and Copper Extrusion
}

\author{
Sunita Dey, Dongli Zeng, Paul Adamson, Jordi Cabana, Sylvio Indris, Jingyu Lu, Simon J. Clarke,* \\ and Clare P. Grey*
}

Cite This: Chem. Mater. 2021, 33, 3989-4005

Read Online

ACCESS | 亗 Metrics \& More |回 Article Recommendations

SI Supporting Information

ABSTRACT: The electrochemical lithiation and delithiation of the layered oxysulfide $\mathrm{Sr}_{2} \mathrm{MnO}_{2} \mathrm{Cu}_{3.5} \mathrm{~S}_{3} \stackrel{V}{\mathrm{Reversible}} \mathrm{Charged}_{3.7 \mathrm{~V}}$ $\mathrm{Sr}_{2} \mathrm{MnO}_{2} \mathrm{Cu}_{4-\delta} \mathrm{S}_{3}$ has been investigated by using a combination of in situ powder X-ray diffraction and $e x$ situ neutron powder diffraction, X-ray absorption and ${ }^{7} \mathrm{Li}$ NMR spectroscopy, together with a range of electrochemical experiments. $\mathrm{Sr}_{2} \mathrm{MnO}_{2} \mathrm{Cu}_{4-\delta} \mathrm{S}_{3}$ consists of $\left[\mathrm{Sr}_{2} \mathrm{MnO}_{2}\right]$ perovskite-type cationic layers alternating with highly defective antifluorite-type $\left[\mathrm{Cu}_{4-\delta} S_{3}\right](\delta \approx$ $0.5)$ anionic layers. It undergoes a combined displacement/intercalation (CDI) mechanism on reaction with $\mathrm{Li}$, where the inserted $\mathrm{Li}$ replaces $\mathrm{Cu}$, forming $\mathrm{Li}_{4} \mathrm{~S}_{3}$ slabs and $\mathrm{Cu}^{+}$is reduced and

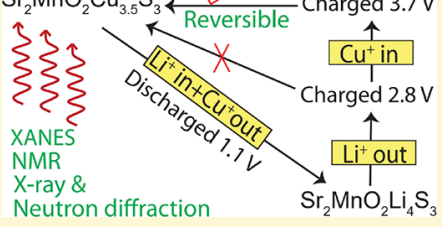
extruded as metallic particles. For the initial $2-3 \%$ of the first discharge process, the vacant sites in the sulfide layer are filled by Li; $\mathrm{Cu}$ extrusion then accompanies further insertion of $\mathrm{Li} . \mathrm{Mn}^{2.5+}$ is reduced to $\mathrm{Mn}^{2+}$ during the first half of the discharge. The overall charging process involves the removal of $\mathrm{Li}$ and re-insertion of $\mathrm{Cu}$ into the sulfide layers with re-oxidation of $\mathrm{Mn}^{2+}$ to $\mathrm{Mn}^{2.5+}$. However, due to the different diffusivities of $\mathrm{Li}$ and $\mathrm{Cu}$, the processes operating on charge are quite different from those operating during the first discharge: charging to $2.75 \mathrm{~V}$ results in the removal of most of the Li, little reinsertion of $\mathrm{Cu}$, and good capacity retention. A charge to $3.75 \mathrm{~V}$ is required to fully reinsert $\mathrm{Cu}$, which results in significant changes to the sulfide sublattice during the following discharge and poor capacity retention. This detailed structure-property investigation will promote the design of new functional electrodes with improved device performance.

\section{INTRODUCTION}

Despite the deep penetration of Li-ion secondary batteries into the market, a need remains to continue to improve them through the optimization of currently available electrode materials and the discovery of new ones due to massive increases in market demands. Electrode materials can be classified into three types based on the mechanisms of (de)lithiation: intercalation, conversion, and displacement. ${ }^{1}$ The most widely used positive electrode ("cathode") materials in commercial rechargeable lithium-ion batteries are intercalation compounds, such as layered $\mathrm{LiCoO}_{2}$, spinel-type $\mathrm{LiMn}_{2} \mathrm{O}_{4}$, olivine-type $\mathrm{LiFePO}_{4}$, and their substituted variants (in particular Ni-rich layered materials). Their electrochemical activity is enabled by the presence of one (or more) $3 \mathrm{~d}$ transition metal redox centers that function as the charge reservoir and a stable framework that is capable of reversible lithium intercalation. These have intrinsic capacity limitations: lithium can only be inserted into the vacant sites in the framework structure and the available charge in these systems is limited by the amount and the extent to which the redox species can change valence. Often, only one electron per transition metal cation is available. This limitation is circumvented in conversion and displacement reactions, leading to a greater capacity. In conversion reactions, metal binary compounds $\mathrm{M}_{x} \mathrm{X}_{y}(\mathrm{M}=\mathrm{Mn}-\mathrm{Cu}, \mathrm{Sn}, \mathrm{Ru}, \mathrm{Mo}, \mathrm{W}$, etc. and $\mathrm{X}=\mathrm{F}, \mathrm{O}, \mathrm{S}, \mathrm{N}, \mathrm{P}$ etc.) are lithiated and the metals are reduced to their elemental state. The structure of the electrode material is completely reorganized, leading to metal nanoparticles embedded or surrounded in a $\mathrm{Li}_{n} \mathrm{X}$ salt. ${ }^{1-5}$ Displacement reactions are related to conversion reactions but usually some part of the framework is preserved during the (de)lithiation processes. Displacement reactions have been observed for several $\mathrm{Cu}-\mathrm{Sn}$ and $\mathrm{Cu}-\mathrm{Sb}$ intermetallic alloys that can function as the negative electrode materials in $\mathrm{Li}$ batteries $^{6-8}$ and even in materials that can act as positive electrodes. $^{9-11}$ A prominent example of the latter is $\mathrm{Cu}_{2.33} \mathrm{~V}_{4} \mathrm{O}_{11}$, ${ }^{10}$ which has a structure consisting of $\left[\mathrm{V}_{4} \mathrm{O}_{11}\right]_{n}$ layers, and interlayer $\mathrm{Cu}$ cations $\left(\mathrm{Cu}^{+}\right.$and $\left.\mathrm{Cu}^{2+}\right)$. When it reacts with $\mathrm{Li}$ electrochemically, a reversible Li-driven process leading to the growth (on discharge) and disappearance (on charging) of $\mathrm{Cu}$ metal dendrites is observed, together with a concomitant exchange of $\mathrm{Li}$ for $\mathrm{Cu}$ in the interlayer sites. It shows a sustainable reversible capacity of over $250 \mathrm{mAh} / \mathrm{g}$ at a voltage around $2.7 \mathrm{~V}^{10}$ Unfortunately, with a decrease in operating current $(\mathrm{C} / 5$ to $\mathrm{C} / 10)$ and/or at a high applied voltage, the growth of $\mathrm{Cu}$ dendrites is exacerbated, leading to the quick failure of $\mathrm{Cu}_{2.33} \mathrm{~V}_{4} \mathrm{O}_{11}$ activity. ${ }^{12}$ This system involves

Received: February 1, 2021

Revised: $\quad$ May 4, 2021

Published: May 24, 2021 
additional lithium intercalation that is charge-compensated by the $\mathrm{V}^{5+} / \mathrm{V}^{4+}$ redox couple, so the mechanism is described as a combination displacement/intercalation (CDI) reaction. $\mathrm{Ag}_{2} \mathrm{~V}_{4} \mathrm{O}_{11}$, which is a cathode in primary lithium batteries, follows a similar mechanism. ${ }^{9,13,14}$

As $\mathrm{Cu}$ is known to be mobile in the spinel structure, the cation/anion mixed-valence thiospinels $\mathrm{CuTi}_{2} \mathrm{~S}_{4}$ $\left(\mathrm{Cu}^{+} \mathrm{Ti}^{3+} \mathrm{Ti}^{4+}\left(\mathrm{S}^{2-}\right)_{4}\right)$ and $\mathrm{CuCr}_{2} \mathrm{~S}_{4}\left(\mathrm{Cu}^{+}\left(\mathrm{Cr}^{3+}\right)_{2}\left(\mathrm{~S}^{2-}\right)_{3} \mathrm{~S}^{-}\right)$ have also been examined. ${ }^{15,16} \mathrm{CuTi}_{2} \mathrm{~S}_{4}$ undergoes a $\mathrm{CDI}$ reaction in the initial stages of the first discharge (up to $2 \mathrm{Li}$ inserted), where $\mathrm{Li}$ intercalation into the $\mathrm{Ti}_{2} \mathrm{~S}_{4}$ framework is associated with extrusion of elemental $\mathrm{Cu}$ and complete reduction of $\mathrm{Ti}^{4+}$ to $\mathrm{Ti}^{3+}$. The electrochemical reaction of $\mathrm{CuCr}_{2} \mathrm{~S}_{4}$ with $\mathrm{Li}$ initially also occurs through a CDI reaction, with the reduction of $\mathrm{Cu}$ and $\mathrm{S}^{-}$, but $\mathrm{Cu}$ cannot be totally reduced and extruded (the end-of-discharge phase is $\mathrm{Li}_{1.75} \mathrm{Cu}_{0.25} \mathrm{Cr}_{2} \mathrm{~S}_{4}$ ), and the reaction is only partially reversible. The differences between these two thiospinels have been ascribed to the higher mobility of $\mathrm{Cu}$ in $\mathrm{CuTi}_{2} \mathrm{~S}_{4}$ than in $\mathrm{CuCr}_{2} \mathrm{~S}_{4} \cdot{ }^{17} \mathrm{~A}$ systematic study on a few other $\mathrm{Cu}-\mathrm{V}-\mathrm{O}$ and $\mathrm{Cu}-\mathrm{V}-\mathrm{S}$ systems has revealed that the dimensionality and flexibility of the framework structure, together with the $\mathrm{Cu}$ mobility in the material, play important roles in governing the CDI reactions. ${ }^{17}$ More recently, $\mathrm{Li}_{2} \mathrm{Cu}_{2} \mathrm{O}\left(\mathrm{SO}_{4}\right)_{2}$, has been investigated as a $4.7 \mathrm{~V} \mathrm{Li}$ ion battery cathode. Although such a high voltage promotes electrolyte decomposition, the mechanistic study showed that $\mathrm{Li}_{2} \mathrm{Cu}_{2} \mathrm{O}\left(\mathrm{SO}_{4}\right)_{2}$ utilizes the $\mathrm{Cu}^{2+/} \mathrm{Cu}^{3+}$ couple at $4.7 \mathrm{~V}$, while the reaction pathway follows either $\mathrm{Li}$ (de)insertion or complex displacement-conversion pathways depending on the voltage window. ${ }^{18}$

Another class of compounds that shows a displacement mechanism upon reaction with $\mathrm{Li}$ are the oxysulfides, e.g., $\mathrm{Sr}_{2} \mathrm{MnO}_{2} \mathrm{Cu}_{2 m-\delta} \mathrm{S}_{m+1}(m=1,2$, and $3, \delta \approx 0.5) .{ }^{19,20}$ These materials consist of alternating perovskite-type $\left[\mathrm{Sr}_{2} \mathrm{MnO}_{2}\right]$ sheets and antifluorite-type $\left[\mathrm{Cu}_{2} \mathrm{~S}\right]$ slabs of varying thickness in which $\mathrm{Cu}^{+}$ions occupy tetrahedral sites. Since $\delta$ is 0.5 in these compounds when synthesized using standard high temperature solid-state methods, the resulting vacant sites on the $\mathrm{Cu}^{+}$ sublattice are charge-compensated by mixed valency on the $\mathrm{Mn}$ sites (the average $\mathrm{Mn}$ oxidation state is +2.5 ). Previous studies have shown that $\mathrm{Li}$ can be both chemically ${ }^{21}$ and electrochemically ${ }^{22,23}$ inserted into the structure and elemental $\mathrm{Cu}$ extruded and that these reactions are reversible. Neutron powder diffraction (NPD) data for the chemically lithiated phases, ${ }^{21}{ }^{7} \mathrm{Li}$ NMR characterization, ${ }^{22}$ and scanning X-ray fluorescence imaging study ${ }^{24}$ of the electrochemically lithiated phases have confirmed that the inserted $\mathrm{Li}$ ions replace $\mathrm{Cu}$ in the tetrahedral sites of the sulfide layers, with extrusion of metallic $\mathrm{Cu}$. The charge capacity of the $\mathrm{Sr}_{2} \mathrm{MnO}_{2} \mathrm{Cu}_{2 m-\delta} \mathrm{S}_{m+1}$ oxysulfides is proportional to the thickness of the sulfide layers.

The cyclability of these materials has been tested in $\mathrm{Li}$ batteries using a voltage window of 1.1 to $2.7 \mathrm{~V}$, and the results have shown that (i) the retention of charge capacity in these oxysulfides largely depends on the thickness of the $\mathrm{Cu}_{2} \mathrm{~S}$ layer, the $m=3$ member shows the largest capacity; (ii) better performance in cycling but lower capacity was observed for the compounds with thinner sulfide layers (for $m=1$ ); and (iii) the cycling performance of antifluorite-type $\mathrm{Cu}_{2} \mathrm{~S}$ (regarded as the end member with infinite thickness of the $\mathrm{Cu}_{2} \mathrm{~S}$ layer) under similar conditions was poor, meaning that the rigid perovskite-type $\left[\mathrm{Sr}_{2} \mathrm{MnO}_{2}\right]$ layers in the structure seem to play a key role in providing structural stability of the framework upon $\mathrm{Cu}$ extrusion. The $\mathrm{Cu}^{+}$vacancies in the sulfide layer, and the consequent variability in the $\mathrm{Mn}$ oxidation state, provide another contribution to the capacity on cycling. The electrochemical profiles of analogues $\mathrm{Sr}_{2} \mathrm{MO}_{2} \mathrm{Cu}_{2} \mathrm{~S}_{2}$ with different transition metal cations $(\mathrm{M}=\mathrm{Ni}$ or $\mathrm{Co})$ are found to be distinctly different from the $\mathrm{Sr}_{2} \mathrm{MnO}_{2} \mathrm{Cu}_{2 m-\delta} \mathrm{S}_{m+1}$ systems. Co and $\mathrm{Ni}$ compounds contain many fewer vacancies in the $\mathrm{Cu}_{2} \mathrm{~S}_{2}$ layers than the analogues with the more readily oxidized $\mathrm{Mn}$ cations, indicating that the composition of the oxide layer and/or the presence of vacancies in the copper sulfide slabs affects the lithiation processes. ${ }^{23,25,26}$ Recent work has also shown that anion redox involving sulfur can be important in controlling reaction pathways. For example, sulfides such as $\mathrm{VS}_{4}{ }^{27,28}$ and $\mathrm{Li}_{2} \mathrm{FeS}_{2}{ }^{29}$ undergo reversible ion intercalation/deintercalation reactions involving coupled $\mathrm{S}^{2-}$ / $\mathrm{S}_{2}{ }^{2-}$ beside transition-metal redox couples.

In this paper, we describe a detailed investigation of the electrochemical behavior of the $m=2$ member of the $\mathrm{Sr}_{2} \mathrm{MnO}_{2} \mathrm{Cu}_{2 m-\delta} \mathrm{S}_{m+1}$ series, $\mathrm{Sr}_{2} \mathrm{MnO}_{2} \mathrm{Cu}_{4-\delta} \mathrm{S}_{3}$ (denoted as $\mathrm{MnCu}(\mathrm{II})$ hereafter) (Figure 1) upon lithiation and

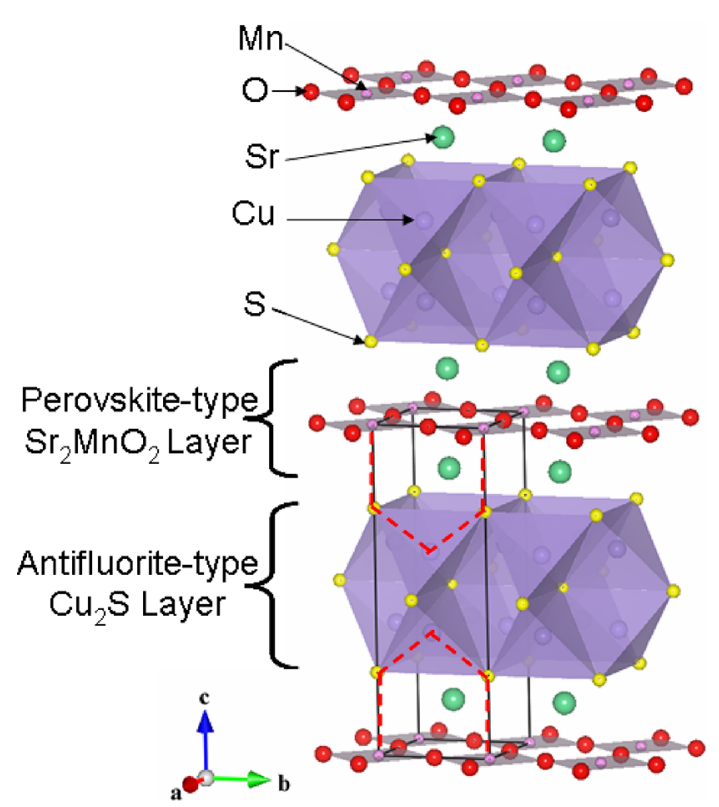

Figure 1. Crystal structure of $\mathrm{Sr}_{2} \mathrm{MnO}_{2} \mathrm{Cu}_{3.5} \mathrm{~S}_{3}(\mathrm{MnCu}(\mathrm{II}))$. The unit cell is indicated with black solid lines, the " $\mathrm{MnO}_{2}$ " square planes and " $\mathrm{CuS}_{4}$ " tetrahedra are shown in gray and purple, respectively. $\mathrm{Sr}$ : green, $\mathrm{Mn}$ : pink, $\mathrm{O}$ : red, $\mathrm{Cu}$ : blue, and $\mathrm{S}$ : yellow. The connectivities between the $\mathrm{Cu}$ and/or vacancy and two $\mathrm{Mn}$ (above or below) via bonds with $S$ are highlighted with red dashed lines.

delithiation. These materials were initially studied because of the potential of achieving materials that coupled some of the best properties of oxides and sulfides, namely, higher redox potentials and higher $\mathrm{Li}^{+}$mobilities, respectively. $\mathrm{MnCu}$ (II) contains 3.5 of $\mathrm{Cu}^{+}$ions per formula unit $\left(\mathrm{Sr}_{2} \mathrm{MnO}_{2} \mathrm{Cu}_{3.5} \mathrm{~S}_{3}\right)$, sufficient to occupy $7 / 8$ of the tetrahedral sites in the sulfide layers. ${ }^{20}$ Previous studies have concluded that, upon lithiation, $\mathrm{Cu}^{+}$and $\mathrm{Mn}^{2.5+}$ are reduced to $\mathrm{Cu}$ metal and $\mathrm{Mn}^{2+}$, respectively, so, in total, $4 \mathrm{Li}^{+}$ions are inserted into $\mathrm{MnCu}(\mathrm{II}) .{ }^{23,24}$ However, the reactions accompanying electrochemical insertion of $\mathrm{Li}$ and extrusion of $\mathrm{Cu}$ have not been explored in detail. Charging up to $2.7 \mathrm{~V}\left(\mathrm{vs} \mathrm{Li} / \mathrm{Li}^{+}\right)$is observed to be insufficient to extract all $4 \mathrm{Li}^{+}$ions; however, the details of the delithiation mechanism, when charged up to $2.7 \mathrm{~V}$, has 
not been explored so far. $^{24}$ Moreover, charging (as well as cyclability) above $2.7 \mathrm{~V}$ has not been explored to date; therefore, the device performance in the upper voltage range $(>2.7 \mathrm{~V})$ and the associated mechanisms are unknown.

This paper describes the structural changes during both the discharge and charge processes characterized by in situ powder $\mathrm{X}$-ray diffraction (PXRD), ex situ neutron powder diffraction (NPD), and ex situ ${ }^{7} \mathrm{Li}$ NMR measurements. Ex situ X-ray absorption near-edge structure (XANES) measurements at the $\mathrm{Cu}, \mathrm{Mn}$, and $\mathrm{S} \mathrm{K}$ edges have been analyzed to examine changes in oxidation states and local environments. Our results show that the $\mathrm{Sr}_{2} \mathrm{MnO}_{2}$ layer is far more than merely a structurally rigid "spacer" and is indeed redox-active, and we describe how the behavior is dependent on the charging voltage. This is important so as to understand their promising behavior, to assess mechanisms, and to guide the search of new functional electrode systems with improved performance.

\section{EXPERIMENTAL SECTION}

2.1. Sample Preparation. $\mathrm{Sr}_{2} \mathrm{MnO}_{2} \mathrm{Cu}_{3.5} \mathrm{~S}_{3}$ was prepared as described previously ${ }^{20}$ by grinding together inside an argon-filled dry box, $\mathrm{SrS}, \mathrm{MnO}_{2}, \mathrm{Mn}, \mathrm{CuO}$, and $\mathrm{Cu}_{2} \mathrm{~S}$ in the ratio 2:0.25:0.75:1.5:1. Pellets of this mixture were heated in an alumina-lined evacuated silica ampoule at $1000{ }^{\circ} \mathrm{C}\left(\right.$ ramp rate $\left.10{ }^{\circ} \mathrm{C} / \mathrm{min}\right)$ for $18 \mathrm{~h}$. Electrochemically lithiated samples of $\mathrm{MnCu}$ (II) were recovered from Li batteries after reaching the desired state of charge (SOC) or depth of discharge (DOD). The electrode mixture consisting of $80 \mathrm{wt} \%$ of the oxysulfide, $10 \mathrm{wt} \%$ of acetylene black, and $10 \mathrm{wt} \%$ of polyvinylidene fluoride (PVDF) binder in $N$-methylpyrrolidone (NMP) was coated on a $\mathrm{Al}$ current collector. The batteries were assembled as coin cells (CR2032, Hohsen Corp.) in an argon-filled glove box. Each cell typically contains about $15 \mathrm{mg}$ of oxysulfide, separated from a metallic $\mathrm{Li}$ (0.38 mm-thick foil, Aldrich, 99.9\%) negative electrode by two pieces of Celgard separator (Celgard Inc., USA). A $1 \mathrm{M}$ solution of $\mathrm{LiPF}_{6}$ in ethylene carbonate (EC):dimethyl carbonate (DMC) (1:1) was used as the electrolyte. The electrochemical experiments were carried out with a battery cycler in galvanostatic mode at a current density of $9.35 \mathrm{~mA} / \mathrm{g}$ (a C/20 rate where $\mathrm{C}$ is defined as the theoretical capacity of the compound, $187 \mathrm{mAh} / \mathrm{g}$ ). The cells were opened in the glove box, and the cathode films were washed with DMC and dried in a glove box atmosphere. The resulting samples were recovered in powder form and packed in rotors for ex situ NMR measurements and sealed as films with Kapton and Mylar tapes for ex situ PXRD and XANES experiments. Samples for powder neutron diffraction were obtained by scaling up the electrochemical syntheses.

Open-circuit potential data were collected by using the galvanostatic intermittent titration technique (GITT). Here, a constant current corresponding to a C/20 rate was applied for $4 \mathrm{~h}$ (during the first cycle between 1.1 and $3.75 \mathrm{~V}$ ) or $1 \mathrm{~h}$ (during the second discharge from 2.75 to $1.1 \mathrm{~V}$ ) followed by a rest period of $8 \mathrm{~h}$ for each step.

2.2. In Situ Powder X-ray Diffraction (PXRD). In situ PXRD data were collected on beamline X18A at the National Synchrotron Light Source (NSLS) at Brookhaven National Laboratory (BNL), USA. The radiation wavelength was $0.9999 \AA$, and a step size of $0.02^{\circ}$ $2 \theta$ was used. A specially designed cell (for in situ measurements) ${ }^{30}$ with Mylar windows was used to cycle the electrode films prepared as described above. Discharge to $1.1 \mathrm{~V}$ and subsequent charging to $2.8 \mathrm{~V}$ and partial discharging was accomplished over $48 \mathrm{~h}$.

2.3. Ex Situ Neutron Powder Diffraction (NPD). Ex situ neutron powder diffraction data were collected at $300 \mathrm{~K}$ for materials extracted from electrochemical cells on the POLARIS diffractometer at the ISIS facility, Rutherford Appleton Laboratory, UK. Batches of $0.2-0.4 \mathrm{~g}$ of the material were loaded into $6 \mathrm{~mm}$ diameter cylindrical vanadium cans sealed with indium gaskets inside an $\mathrm{Ar}$-filled glove box to avoid any exposure to air and moisture. Data were collected for an integrated proton current at the target of between 1800 and 2500 $\mu \mathrm{A} \mathrm{h}$ (dependent on the size of the sample). Rietveld refinement was carried out using the software package GSAS ${ }^{31}$ and its graphical user interface EXPGUI. ${ }^{32}$ The diffraction patterns collected have large backgrounds containing diffuse features, which are due to scattering from the acetylene black, added to improve conductivity. Due to the small sample volumes, Bragg peaks resulting from the vanadium sample cans were present in all the diffraction patterns.

2.4. X-ray Absorption Near-Edge Spectroscopy (XANES). XANES spectra were collected on beamline X19A at the NSLS at BNL, USA. The measurements were performed in transmission (for $\mathrm{Mn}$ and $\mathrm{Cu}$ ) or fluorescence (for S) mode using a Si (111) doublecrystal monochromator detuned to $35-45 \%$ of its original intensity to eliminate the higher order harmonics. Energy calibration was carried out using the first inflection points in the spectra of $\mathrm{Mn}$ and $\mathrm{Cu}$ metal foil as references $(\mathrm{Mn} \mathrm{K}$-edge $=6539 \mathrm{eV}$, Cu K-edge $=8979 \mathrm{eV})$. The $\mathrm{S}$ K-edge XANES spectra were calibrated against the native sulfur Kedge at $2472 \mathrm{eV}$.

2.5. Solid-State Nuclear Magnetic Resonance (NMR) Spectroscopy. The ${ }^{7} \mathrm{Li}$ magic-angle spinning (MAS) NMR experiments were performed at $77.8 \mathrm{MHz}$ on a Chemagnetics CMX-200 spectrometer $\left(\mathrm{B}_{0}=4.7 \mathrm{~T}\right)$ by using a double resonance $1.8 \mathrm{~mm}$ probe. Silicon nitride $\left(\mathrm{Si}_{3} \mathrm{~N}_{4}\right)$ rotors were used and spun at a speed of $38 \mathrm{kHz}$. All the spectra were acquired following a rotor-synchronized Hahn echo sequence $\left(90^{\circ}-\tau\right.$ - $180^{\circ}-\tau$-acquisition $)$. The spectra were referenced to a standard $1 \mathrm{M} \mathrm{LiCl}$ solution at $0 \mathrm{ppm} . \pi / 2$ pulses of 2 $\mu$ s were typically used, with a delay time of $1 \mathrm{~s}$.

\section{RESULTS}

3.1. Electrochemistry. Figure 2 shows the voltagecomposition curves of lithium batteries using $\mathrm{MnCu}(\mathrm{II})$ as positive electrodes and cycled between 1.1 and $2.75 \mathrm{~V}$ and between 1.1 and $3.75 \mathrm{~V}$ (see Table S1). After a process at around 2.1 to $2.2 \mathrm{~V}$, which accounts for around $5 \mathrm{mAh} / \mathrm{g}(0.1$ $\mathrm{Li}$ or $2.5 \%$ ) of the capacity, the first discharge curve of $\mathrm{MnCu}(\mathrm{II})$ displays a long plateau at around $1.5 \mathrm{~V}$, before reaching a capacity equivalent to about $4 \mathrm{~mol}$ of $\mathrm{Li}$ insertion per formula unit $(187 \mathrm{mAh} / \mathrm{g})$ at $1.1 \mathrm{~V}$. The large capacity of this process suggests that it corresponds to $\mathrm{Li}^{+}$ions completely replacing the $\mathrm{Cu}^{+}$ions as well as occupying the vacant tetrahedral sites. Results from open-circuit voltage electrochemical measurements (GITT, Figure S1, Supporting Information) suggest an overpotential of around $0.2 \mathrm{~V}$ for the long plateau during the first discharge.

During the following charge to $2.75 \mathrm{~V}$ (Figure 2a), two distinct processes, at around 1.8 and $2.5 \mathrm{~V}$, are resolved, which together account for $80 \%$ of the discharge capacity (i.e., there is $20 \%$ capacity loss after the first cycle when the system is charged to $2.75 \mathrm{~V}$ ). The equilibrium potential for the " $1.8 \mathrm{~V}$ " process is around $1.7 \mathrm{~V}$ (Figure S1a), very close to the potential of the second half of the $1.5 \mathrm{~V}$ process during the first discharge, suggesting that the species involved in the reaction may be the same.

The profile of the second discharge following charging to $2.75 \mathrm{~V}$ is different from that of the first discharge: two plateaus, at around 2.2 and $1.5 \mathrm{~V}$ are observed, each accounting for roughly half of the total capacity. The GITT results (see Figure $\mathrm{S} 1 \mathrm{~b}$, Supporting Information) show that the equilibrium voltage of the " $2.2 \mathrm{~V}$ " discharge process and the " $2.5 \mathrm{~V}$ " charge process are similar. The two plateaus at 2.2 and $1.5 \mathrm{~V}$ are observed during subsequent cycles, a sign of good cyclability, and little loss of capacity is seen beyond that lost between the first and second discharges within the voltage window of $1.1-2.7 \mathrm{~V}^{22}$ Furthermore, these two processes are similar to the two plateaus at around 2.1 and $1.7 \mathrm{~V}$ observed for $\mathrm{CuS}$ during the first discharge in a Li battery, ${ }^{33,34}$ except the capacity corresponding to each plateau is much smaller 


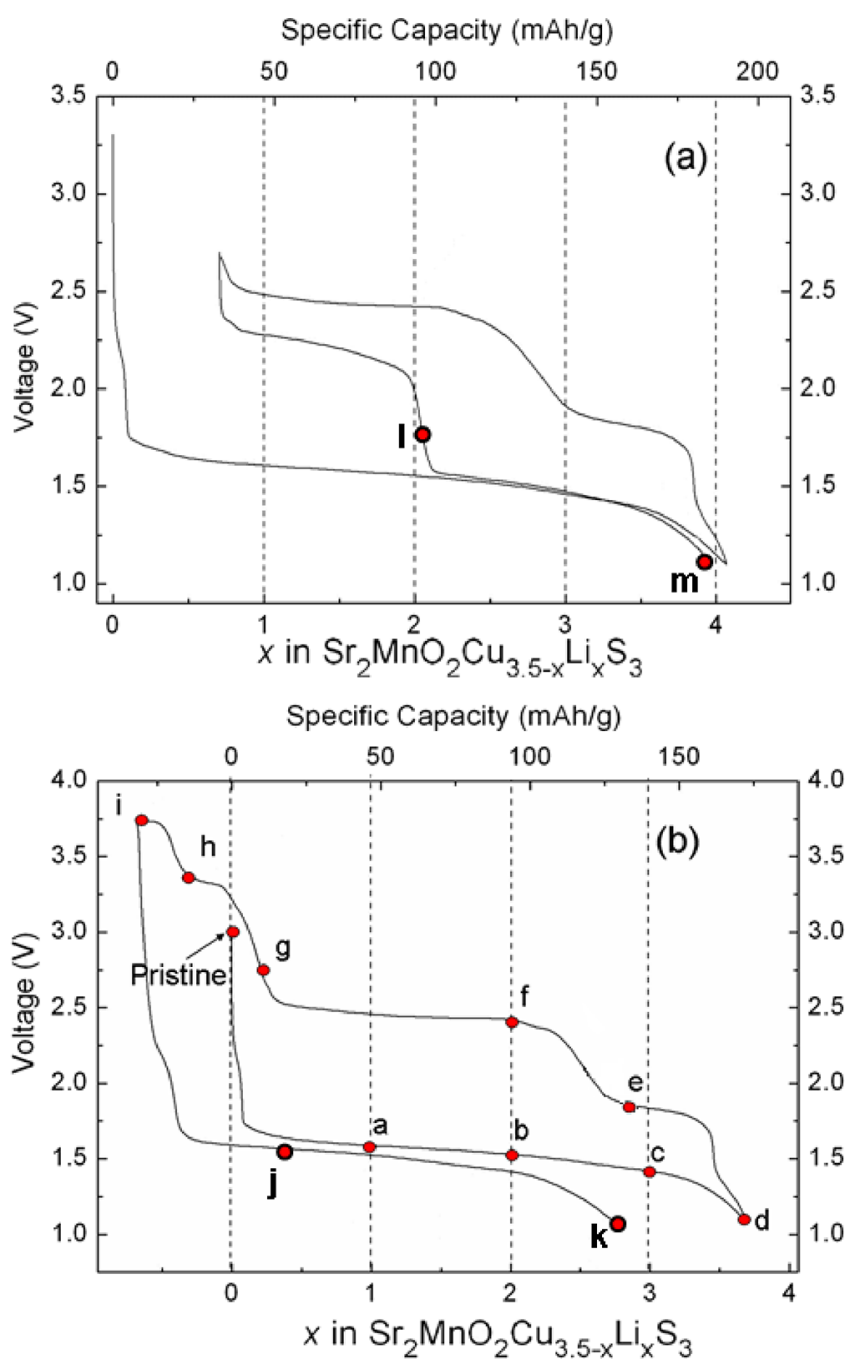

Figure 2. Plot of the voltage vs Li content and specific capacity of lithium batteries with $\mathrm{MnCu}$ (II) as the positive electrodes, cycled at a $\mathrm{C} / 20$ rate. The curves shown here include the complete first cycle (discharge and charge) and the second discharge for a battery cycled between (a) 1.1 and $2.75 \mathrm{~V}$ and (b) 1.1 and $3.75 \mathrm{~V}$. The red points labeled at different stages of (dis)charge show the compositions of samples $a-m$ prepared for the ex situ measurements. Summary of these processes are presented in Table S1, Supporting Information.

than that observed for $\mathrm{CuS}$ due to the much lower formula weight of $\mathrm{CuS}$.

In contrast, when a battery was charged to $3.75 \mathrm{~V}$, a voltage that is higher than that required to oxidize $\mathrm{Cu}^{0}(\sim 3.56 \mathrm{~V}),{ }^{35}$ an additional capacity of approximately $30 \mathrm{mAh} / \mathrm{g}$, was observed in Figure $2 \mathrm{~b}$. This extra capacity could be due to the oxidation of $\mathrm{Cu}^{0}$ remaining during earlier in the charge process to $\mathrm{Cu}^{+}$, which could either displace the remaining $\mathrm{Li}$ in the structure and/or migrate into the electrolyte. These hypotheses will be discussed below. A similar process was described earlier for the $\mathrm{Li}_{x} \mathrm{CuTi}_{2} \mathrm{~S}_{4}$ system: capacities observed at $3.75 \mathrm{~V}$ were associated with the re-insertion of residual $\mathrm{Cu}$ into the structure that still remained in the electrode after charging at lower potentials and the removal of all of the $\mathrm{Li}$, according to PXRD results. ${ }^{15}$

The cutoff voltage for the first charge clearly has an effect on the subsequent second discharge. When the first charge goes to $3.75 \mathrm{~V}$, the second discharge curve closely follows that obtained for the first discharge, suggesting that the pristine structure of the oxysulfide is largely restored on charging the system to $3.75 \mathrm{~V}$. The overall capacity is about $8 \%$ lower during the second discharge than the first. The drop in capacity on the second discharge is nearly $20 \%$ when the first charge is to just $2.75 \mathrm{~V}$. However, the cycling performance of $\mathrm{MnCu}$ (II) using the larger voltage window $(1.1-3.75 \mathrm{~V})$ is poorer than when the $1.1-2.75 \mathrm{~V}$ window is used, and the capacity fades quickly to less than $50 \mathrm{mAh} / \mathrm{g}$ after 10 cycles (Figure S2).

In situ PXRD, ex situ PXRD and NPD, XANES, and NMR experiments were carried out to understand the processes occurring during $\mathrm{Li}$ insertion/extraction. The ex situ analyses were performed on samples extracted from batteries at different states, which are marked with red dots and labeled $a-m$ in Figure 2.

3.2. X-ray and Neutron Powder Diffraction Measurements. In situ PXRD was used to probe the evolution of the oxysulfide phase(s) and extruded copper during the first discharge and the subsequent charge to $2.8 \mathrm{~V}$ (Figure 3 ). Separate samples were prepared at points in the first cycle, in the second discharge from $2.8 \mathrm{~V}$, and also when the first charge was continued to $3.75 \mathrm{~V}$ in order to carry out ex situ PXRD (Figure 5) and NPD (Figure 6) measurements. Quantitative analysis of these patterns using Rietveld refinement (Figure S3) was used to investigate the phases and their compositions present during the discharge and charging processes. The refinement of $\mathrm{Sr}_{2} \mathrm{MnO}_{2} \mathrm{Cu}_{3.5} \mathrm{~S}_{3}$ at the start of the discharge and the other oxysulfide phases identified are given in Table S2 in the Supporting Information.

3.2.1. First Discharge. During the first discharge, reflections from elemental $\mathrm{Cu}$ become evident in the patterns $\left[2 \theta=43^{\circ}\right.$ (111) and $\left.51^{\circ}(200)\right]$ as indicated in Figure 3. The reflections due to the oxysulfide phase also change their intensities and positions as the phase becomes lithiated and copper is extruded. The analysis indicates that only one oxysulfide phase (which we designate OS-I) is present during the entire first discharge process to $1.1 \mathrm{~V}$.

The reflections from elemental $\mathrm{Cu}$ initially appear weak and broad. The point where about $0.2 \mathrm{Li}$ per mole of $\mathrm{Sr}_{2} \mathrm{MnO}_{2} \mathrm{Cu}_{3.5} \mathrm{~S}_{3}$ have been inserted the most intense $\mathrm{Cu}$ reflection ((111) reflection) appears as a broad peak but is much narrower and intense by the time 0.5 moles of $\mathrm{Li}$ have been inserted per mole of $\mathrm{Sr}_{2} \mathrm{MnO}_{2} \mathrm{Cu}_{3.5} \mathrm{~S}_{3}$. This is depicted in Figure S4, which shows the Rietveld fits in the early part of the discharge up to point a in the profile (Figure 2 and Figure 3 ). Since there are initially 0.5 moles of vacancies per mole of $\mathrm{Sr}_{2} \mathrm{MnO}_{2} \mathrm{Cu}_{3.5} \mathrm{~S}_{3}$, the diffraction data show that $\mathrm{Cu}$ extrusion starts to occur well before all these vacancies are filled. The short process at $2.2 \mathrm{~V}$ on discharge appears to be associated with pure insertion of $0.1 \mathrm{Li}$ at the start of the discharge, but the signal to noise ratio is not sufficient to exclude the possibility that $\mathrm{Cu}$ extrusion may also be occurring at this point. Along with the appearance of the reflections due to the formation of $\mathrm{Cu}$ metal, the reflections due to the oxysulfide phase change their intensities. In particular, the (001) reflection at $2 \theta=7.7^{\circ}$ gains intensity. This reflection happens to have negligible intensity in $\mathrm{Sr}_{2} \mathrm{MnO}_{2} \mathrm{Cu}_{3.5} \mathrm{~S}_{3}$ (i.e., the magnitude of the structure factor is coincidentally close to zero because of the relative phases of the scattering contributions of all the atoms) but acquires intensity as $\mathrm{Cu}$ is replaced by $\mathrm{Li}$. This is because the transformation is topotactic (i.e., the arrangement of scattering objects is unchanged), but the substitution of the strongly scattering $\mathrm{Cu}^{+}$by the comparatively weakly scattering $\mathrm{Li}^{+}$results in a 

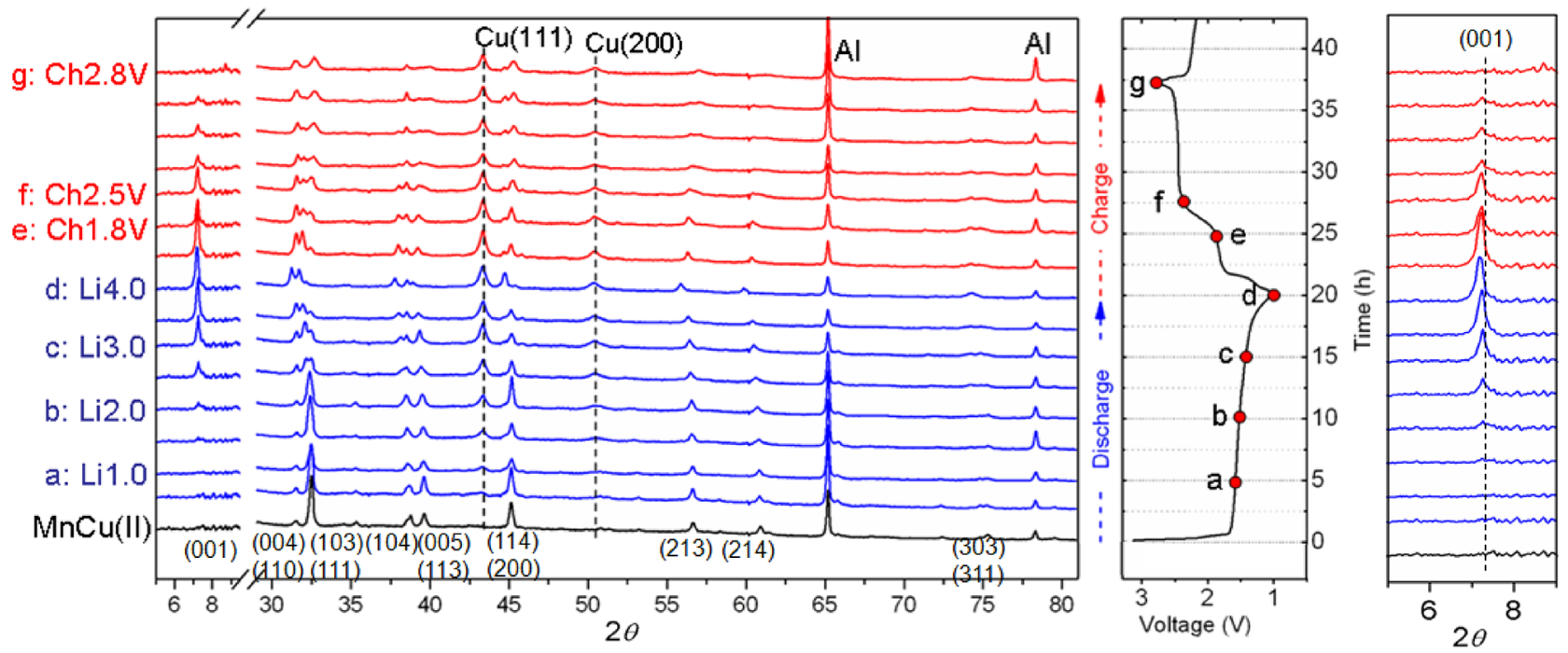

Figure 3. Representative in situ PXRD patterns (left panel) and corresponding electrochemical profile (middle panel) for a $\mathrm{Li} / \mathrm{MnCu}(\mathrm{II})$ cell cycled between 1.1 and $2.8 \mathrm{~V}$ at a C/20 rate. The $2 \theta$ values have been converted to those corresponding to $\mathrm{CuK}_{\alpha}(i . e$., a wavelength of $1.5418 \AA$ ). Selected compositions at different depths/states of discharge/charge are marked with letters $\mathrm{a}-\mathrm{g}$ in the electrochemical profile (using the same letter key as for ex situ samples), and the corresponding Li contents or voltage values are indicated on the XRD patterns. The reflections are indexed for the pristine $\mathrm{MnCu}$ (II) phase. Reflections due to $\mathrm{Cu}$ metal are indicated with dashed lines and are also indexed. The reflections from the $\mathrm{Al}$ foil in the in situ cell are marked. The right panel is a magnification of the region between $5^{\circ}$ and $9^{\circ} 2 \theta$; the dashed line is a guide to the eye showing the highest $2 \theta$ angle reached by the (001) reflection of the oxysulfide.

significant increase in the magnitude of the structure factor for this reflection and hence an increase in the intensity (more details can be found in ref 21).

The in situ data were modeled by using a single oxysulfide phase (OS-I) and modeling the composition by making the assumption that the $\mathrm{Cu} / \mathrm{Li}$ sites are fully occupied and refining the $\mathrm{Cu}: \mathrm{Li}$ ratio (Figure 4). After full discharge to $1.1 \mathrm{~V}$, the lattice parameters show excellent quantitative agreement with those obtained for fully lithiated material obtained by reacting $\mathrm{Sr}_{2} \mathrm{MnO}_{2} \mathrm{Cu}_{3.5} \mathrm{~S}_{3}$ with $n$ - $\mathrm{BuLi}^{21}$ and, in the refined model, the scattering on the tetrahedral sites in the sulfide layer corresponds to full occupancy by $\mathrm{Li}$. The evolution of the lattice parameters during discharge and the subsequent charge (Figure 4) shows that the previously documented $\sim 1.0 \%$ increase in the basal lattice parameter $a$ on lithiation occurs almost wholly during the final $10-15 \%$ of the lithiation process; $^{21}$ this, coupled with the much larger, but steadier increase in $c$, which occurs over the whole of the discharge, leads to a sharp increase in the cell volume at the end of the discharge. At this point in the discharge, a sample composition of $\mathrm{Sr}_{2} \mathrm{MnO}_{2} \mathrm{Cu}_{0.00(3)} \mathrm{Li}_{4.00(3)} \mathrm{S}_{3}$ and $\mathrm{Cu}$ in a 1:3.4(1) mole ratio has been obtained in the refinements (see Table S2). Despite the poor counting statistics of the data and the intrinsic difficulty of disentangling correlated parameters in the Rietveld refinement (notably between site occupancy factors and atomic displacement parameters), the refined composition of OS-I and the refinement of the phase fractions of OS-I and elemental $\mathrm{Cu}$ show that $\mathrm{Cu}$ is gradually replaced by $\mathrm{Li}$ in OS-I during discharge and that a fully lithiated material is obtained at the end of the discharge. The refinements show that the vast majority of the elemental $\mathrm{Cu}$ is present as a crystalline phase, and the apparent total $\mathrm{Cu}$ content in the $\mathrm{Cu}+$ oxysulfide crystalline phases remain constant within the uncertainty during the first discharge (Figure 4c).

For comparison, a larger sample of a material discharged to 1.1 V was also examined with laboratory PXRD and NPD data (Figure 5 and Figure 6) and shows a smaller a lattice parameter than the in situ discharged sample (Table 1). Refinement suggests the composition was $\mathrm{Sr}_{2} \mathrm{MnO}_{2} \mathrm{Cu}_{0.4(1)} \mathrm{Li}_{3.6(1)} \mathrm{S}_{3}$ and elemental $\mathrm{Cu}$ in a 1: 2.9(1) mole ratio, which means that the fully discharged state had not quite been reached. The lower overall lithiation is likely a consequence of scaling up the electrochemical synthesis.

3.2.2. First Charge. The phase behavior during charging is complex. The in situ PXRD measurements were made on charging up to $2.8 \mathrm{~V}$. At the start of the charge, the basal lattice parameter and the cell volume of the single oxysulfide phase (OS-I) decrease rapidly (Figure 4a), presumably as lithium is removed from the lithiated phase. The end of the sharp decrease in cell volume corresponds to the start of the $1.8 \mathrm{~V}$ charging process. At about the mid-point of the $1.8 \mathrm{~V}$ process, the data are best modeled by including a second oxysulfide phase (OS-II), which was not observed at any point during the first discharge. The analysis in the multiphase region was carried out by refining the compositions (i.e., the scattering present on the metal sites in the sulfide layer) as well as the phase fractions of the two oxysulfide phases (OS-I and OS-II) and elemental $\mathrm{Cu}$. The refinements showed that on charging the OS-I phase has only very weakly scattering elements on the tetrahedral sites in the sulfide layer (i.e., as $\mathrm{Li}$ is removed, very little $\mathrm{Cu}$ (less than 0.5 moles per mole of $\mathrm{Mn}$ ) is reinserted into this phase). In contrast, the OS-II phase is relatively $\mathrm{Cu}$ rich, with the scattering on the tetrahedral sites in the sulfide layer corresponding to about 1.8(3) moles of $\mathrm{Cu}$ per mole of $\mathrm{Mn}$ (about half of the amount in $\mathrm{Sr}_{2} \mathrm{MnO}_{2} \mathrm{Cu}_{3.5} \mathrm{~S}_{3}$ ). The refined weight fraction of this $\mathrm{Cu}$-containing OS-II phase increases progressively at the expense of OS-I as charging proceeds. Formation of this OS-II phase upon charge provides an explanation for the asymmetry observed in the voltage trace during the two processes; its origin lies on the fundamentally different mechanisms of reaction that the system follows, depending on whether lithium or copper is inserted or removed. The refined structure of the OS-II phase obtained from the in situ refinements after charging to $2.75 \mathrm{~V}$ where it 

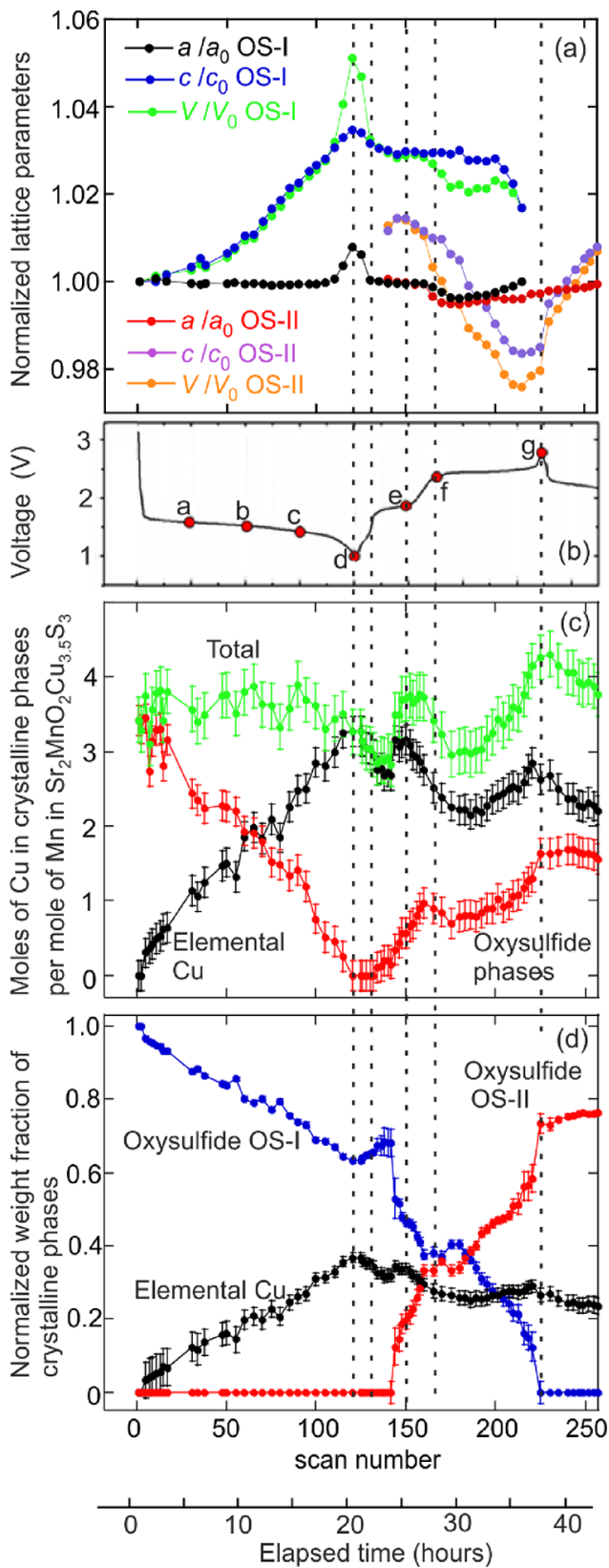

Figure 4. Results of quantitative analysis of the in situ PXRD data obtained during the first discharge followed by charging to $2.8 \mathrm{~V}$ (see Figure S3, Supporting Information for selected Rietveld fits). Panel (a) shows the evolution of the lattice parameters and unit cell volume of the oxysulfide phases OS-I and OS-II. The values have been normalized to those of OS-I (i.e., $\mathrm{Sr}_{2} \mathrm{MnO}_{2} \mathrm{Cu}_{3.5} \mathrm{~S}_{3}$ ) at the start of the discharge. Panel (c) shows the distribution of $\mathrm{Cu}$ amongst the crystalline phases (oxysulfides vs elemental $\mathrm{Cu}$ ). Panel (d) shows the evolution of the weight fraction of the crystalline phases during the cycle. The dotted lines are guides to the eye.

becomes the only oxysulfide phase present is given in Table S2 in the Supporting Information.

The composition of the sample changes rapidly in between the end of the $1.8 \mathrm{~V}$ process (point e) to the start of the $2.5 \mathrm{~V}$ process (point $\mathrm{f}$ ). From the fully discharged state to this point, the amount of elemental $\mathrm{Cu}$ in the sample diminishes and the weight fractions of the $\mathrm{Cu}$-rich OS-II phase and the OS-I phase become approximately equal. To explore this further, ex situ diffraction measurements were carried out on a separate sample charged to a point midway between points e and $f$, corresponding to the region where the composition was changing most rapidly (Figure 5c). Analysis of this ex situ sample showed that a mixture of OS-I and OS-II was present, as in the in situ analysis, although OS-II constituted about twothirds of the oxysulfide phases present, while in the in situ analysis, it constituted about one-half of the oxysulfide phases present. Considering that the $e x$ situ and in situ samples were prepared separately under slightly different conditions and at different scales and that we cannot rule out evolution of the ex situ sample after removal from the cell, these results are comparable. At this point in the charge profile, it is estimated that the oxysulfide phases contain about 2.2 moles of Li per mole of $\mathrm{Mn}$, on the basis of the electrochemistry. From the ex situ refinements, OS-I had lattice parameters very similar to those at the fully discharged (i.e., fully lithiated) state and constituted about one-third of the oxysulfide phases present; refinement suggested a composition $\mathrm{Sr}_{2} \mathrm{MnO}_{2} \mathrm{Li}_{3.6(1)} \mathrm{Cu}_{0.4(1)} \mathrm{S}_{3}$ assuming full site occupancy in the sulfide layers, which is consistent with the composition of this phase obtained from the in situ refinements. OS-II, constituting about two-thirds of the oxysulfide phases present, had much smaller lattice parameters, but they were still larger than those of the parent $\mathrm{Sr}_{2} \mathrm{MnO}_{2} \mathrm{Cu}_{3.5} \mathrm{~S}_{3}$ phase, suggesting that this sample still contained Li. A refinement of the scattering on the tetrahedral sites in the sulfide layers of the OS-II phase was carried out assuming that $\mathrm{Cu}$ only was present in the sulfide layers. This produced a composition of $\mathrm{Sr}_{2} \mathrm{MnO}_{2} \mathrm{Cu}_{2.2(2)} \mathrm{Li}_{x} \mathrm{~S}_{3}$ for this phase OS-II, which is also consistent with the composition obtained in the in situ refinements. To account for the remaining Li that had not been removed at this point in the charging process, we calculate that $x \approx 1.5(2)$ in this sample. The sample contained 1.8 moles of crystalline elemental $\mathrm{Cu}$ per mole of $\mathrm{Mn}$ from the refinement for this ex situ sample, broadly consistent with the in situ data measured at this point in the electrochemical profile, which was obtained in a separate experiment with a different setup. See Table 1 for similar analysis of the other samples. The uncertainties in the refined and calculated compositions are relatively high considering the multiphase nature of the samples.

During the long $2.5 \mathrm{~V}$ process, the lattice parameters of the dominant OS-II phase decrease, but its refined formula weight remains approximately constant. This is consistent with the removal of Li from OS-II, which is not compensated by the reinsertion of $\mathrm{Cu}$, and is expected to lead to the oxidation of $\mathrm{Mn}$. During this process, the amount of $\mathrm{Cu}$ present in the oxysulfide phase remains remarkably constant. In turn, the phase fraction of crystalline elemental $\mathrm{Cu}$ shows an increase during this process. This observation is ascribed to (i) grain growth of $\mathrm{Cu}$ originally extruded as very small particles, (ii) loss of crystallinity of some of the oxysulfide material, and/or (iii) an artifact of the in situ experiment. Most importantly, it is clear that the amount of $\mathrm{Cu}$ inserted into the oxysulfide does not increase significantly during the $2.5 \mathrm{~V}$ process.

At the very end of the $2.5 \mathrm{~V}$ process, the in situ data show that the phase OS-I is no longer required to model the data satisfactorily. The ex situ data obtained for a sample charged at $2.8 \mathrm{~V}$ (corresponding to point $\mathrm{g}$ in the voltage profile in Figure 2) show that, in addition to the OS-II phase, there is a phase present (OS-III) with a $c$ lattice parameter of about $9.8 \AA$, much smaller than even the smallest value attained in the charge for OS-II of about $11.2 \AA$ (Table 1). This phase could not be reliably identified in the in situ data, but in the ex situ 


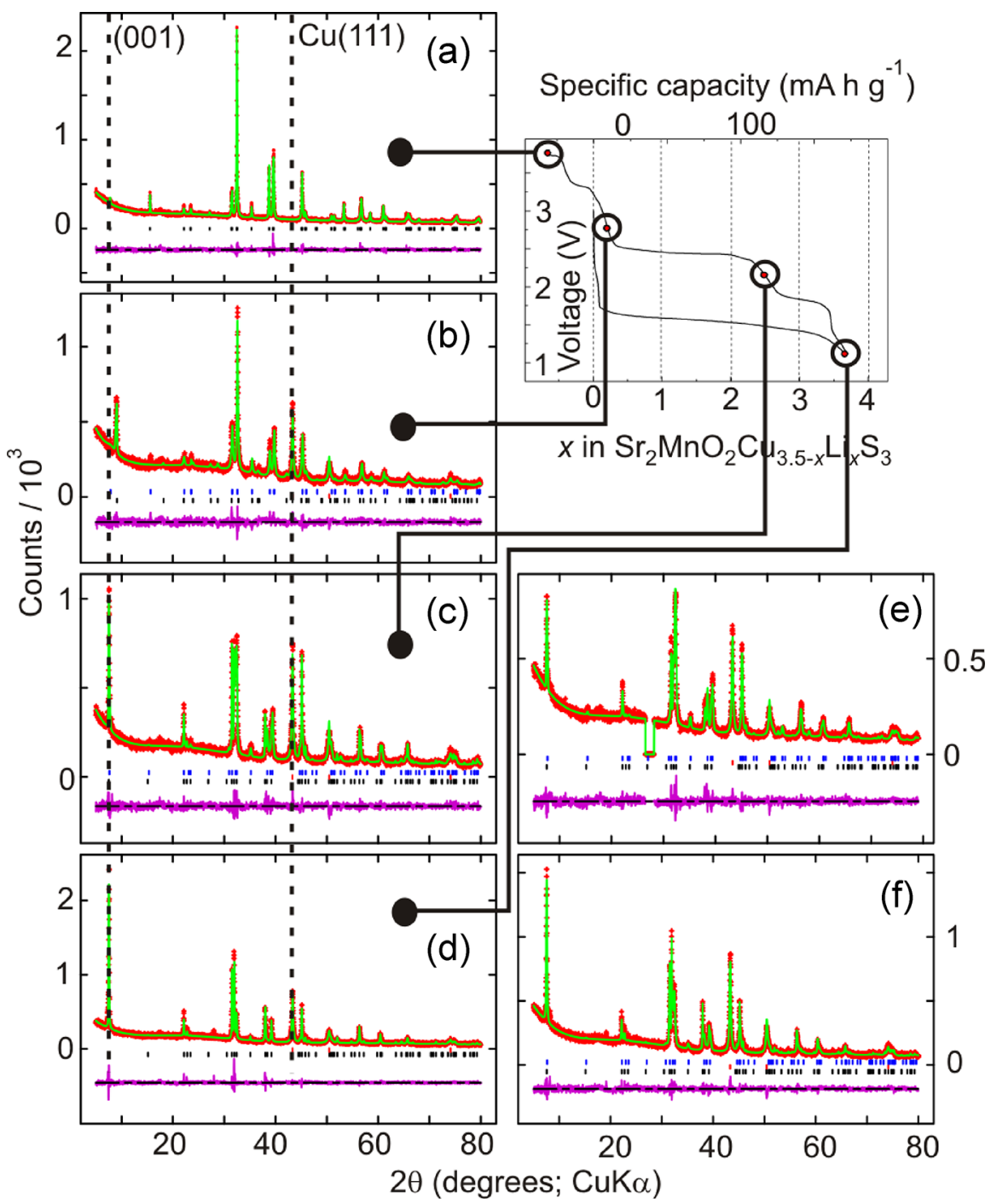

Figure 5. Rietveld refinements against laboratory PXRD data of samples extracted from batteries during the first charge (diffractograms (a)-(d)) at the voltages shown and during the second discharge after charging to $2.8 \mathrm{~V}$ (diffractograms (e) and (f)). Diffractograms (e) and (f) correspond to the 2.2 and $1.1 \mathrm{~V}$ discharged states during the second discharge, respectively. The dotted lines show the position of the most intense (111) reflection from elemental $\mathrm{Cu}$ (which is entirely absent when the battery is charged up to $3.75 \mathrm{~V}$ ) and the position of the (001) reflection in Cu or $\mathrm{Li}$ containing oxysulfide phases. The position of this (001) reflection shifts to a much higher $2 \theta$ for a minority phase (OS-III) present in diffractogram (b), and this phase is tentatively modeled as a "collapsed" oxysulfide phase completely devoid of cations in the sulfide layer. Corresponding fits to NPD data for the same samples are shown in Figure 6.

data, the appearance of this phase, with its intense 001 reflection, is very clear (Figure $5 b$ ). The overall composition at point $\mathrm{g}$ is refined to be $\mathrm{Sr}_{2} \mathrm{MnO}_{2} \mathrm{Cu}_{2.0(2)} \mathrm{Li}_{0.5(2)} \mathrm{S}_{3}$ and elemental $\mathrm{Cu}$ in a $1: 1.7(2)$ ratio.

According to the ex situ PXRD and NPD refinements and with the Li content inferred from the position on the charge curve, this OS-III phase constitutes approximately $20 \mathrm{~mol} \%$ of the oxysulfides present (Figure $5 \mathrm{~b}$ and Figure 6). Although the refinement of the structure of this phase with its short $c$ lattice parameter against the data available is hampered by the fact that it is present only as a minority phase, the contraction of the $c$ axis suggest that it has no or few cations present in the sulfide layers and is an oxysulfide with a collapsed sulfide layer, which, in the limit, would have a composition $\mathrm{Sr}_{2} \mathrm{MnO}_{2} \mathrm{~S}_{3}$. Given the small fraction of this phase, it was modeled in the refinements as a collapsed phase with a similar arrangement of ions to OS-I or OS-II, but with the metal ions removed from the sulfide layers, and with shorter $S-S$ distances resulting from the significant shortening of the $c$ axis. Attempted refinement of the structure of this minority phase was not possible given the small phase fraction, and further investigations of this phase are needed to determine the coordination environment of the sulfide ions and whether some residual metal ions are accommodated in the collapsed sulfide layer. The extreme composition for OS-III of $\mathrm{Sr}_{2} \mathrm{MnO}_{2} \mathrm{~S}_{3}$ would require that electrons are removed from the sulfide-based valence band and/or sulfide-sulfide bonds are formed. We suggest that this third minority phase (OS-III) is the result of the collapse of the lithiated phase OS-I when all the $\mathrm{Li}$ is deintercalated, though further characterization of this phase is required. Given that $\mathrm{Li}$ is a feeble scatterer of $\mathrm{X}$-rays and due to the low quality of the neutron data and the fact that sites may be partially occupied by $\mathrm{Cu}, \mathrm{Li}$ or be vacant, it is not possible to determine using these the diffraction data alone whether any Li remains in the oxysulfide phases (mainly OSII) after the system has been charged to $2.8 \mathrm{~V}$, but from the 


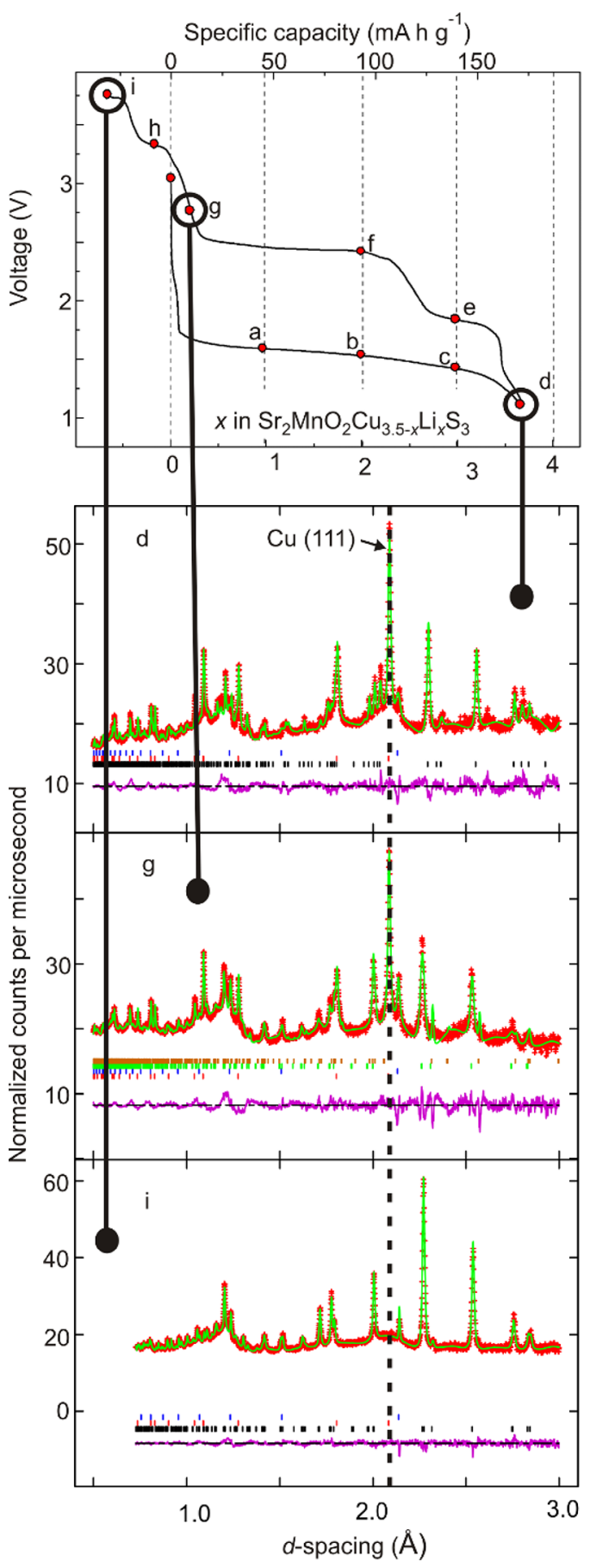

Figure 6. Rietveld analysis of NPD data (POLARIS, ISIS facility) of samples extracted from batteries that were fully discharged (d), charged to $2.8 \mathrm{~V}(\mathrm{~g})$, and charged to $3.7 \mathrm{~V}(\mathrm{i})$. The dotted line is a guide to the eye, which shows that the strongest (111) peak due to elemental $\mathrm{Cu}$ is not discernable in the sample charged to $3.7 \mathrm{~V}$.

position in the charge profile and the NMR results presented below, it is clear that some Li remains in the oxysulfide phases, although it cannot be concluded whether both the majority OS-II phase and the minority OS-III phase contain this remnant Li.

Continued charging to $3.7 \mathrm{~V}$ (point i) restores a single oxysulfide phase, and the ex situ laboratory X-ray (Figure 5a) and NPD data (Figure 6) show no measurable quantity of crystalline elemental $\mathrm{Cu}$. PXRD and NPD refinements produced a composition of $\mathrm{Sr}_{2} \mathrm{MnO}_{2} \mathrm{Cu}_{3.5(2)} \mathrm{S}_{3}$ for this final single oxysulfide phase. The lattice parameters were $0.3 \%(a)$, $0.15 \%(c)$, and $0.6 \%$ (volume) smaller than for single phase pristine $\mathrm{Sr}_{2} \mathrm{MnO}_{2} \mathrm{Cu}_{3.5} \mathrm{~S}_{3}$, suggesting that the product may be slightly $\mathrm{Cu}$-deficient relative to the original starting material.

3.2.3. Second Discharge. When samples were discharged to $1.1 \mathrm{~V}$, charged to $2.8 \mathrm{~V}$, and then discharged, the phases formed were found to be similar to those produced during the first charge processes (Figure 5e,f). Such similarities are consistent with the observation that the voltage trace during this second discharge mirrors that of the first charge (Figure $2 \mathrm{a})$. Furthermore, the sample obtained after the $2.2 \mathrm{~V}$ process on discharge corresponded closely to that obtained at the same state on charging, as shown side by side on Figure $5 \mathrm{c}$ and Figure 5e, respectively. However, at point $m$, the structural refinement was found to require two phases, one of which was $\mathrm{Cu}$-rich (Figure 5f). Therefore, the second discharge is not as efficient a process of $\mathrm{Cu}$ extrusion as the first. We suggest that the structural changes required to precipitate metallic particles out of a framework introduces a strain that damages the particles and renders them less active upon subsequent cycling. Upon cycling, this electrochemical grinding, coupled with copper dissolution, is expected to continue, contributing to the capacity loss reported in a previous report. $^{22}$

3.3. Ex Situ XANES Analysis. 3.3.1. First Discharge. The mean $\mathrm{Mn}$ oxidation state in $\mathrm{MnCu}$ (II) is +2.5 based on the size of the effective moment per $\mathrm{Mn}$ ion in the Curie-Weiss region and XANES measurements. ${ }^{20}$ On electrochemical $\mathrm{Li}$ insertion, the Mn K-edge absorption shifts to a lower energy (Figure 7), indicating that $\mathrm{Mn}$ is reduced during discharge. This process of reduction is largely complete at sample b (Li2.0), halfway through the first discharge. Thereafter, the absorption edge does not show a significant shift but a noticeable change in shape that is ascribed to structural changes in the local coordination of $\mathrm{Mn}$. In $\mathrm{MnCu}$ (II), $\mathrm{Mn}$ is located in an axially distended octahedral site with four oxide and two sulfide ions in the equatorial and axial positions, respectively. As $\mathrm{Li}$ is inserted into the sulfide layer and $\mathrm{Cu}$ is extruded from it, significant changes to the sulfide environments are expected, which in turn may influence the $\mathrm{Mn}$ environment. The normalized $\mathrm{Cu}$ K-edge XANES spectra of $\mathrm{MnCu}(\mathrm{II})$ during the first discharge and their corresponding first derivatives (Figure S5) show a slight broadening but very little shift in the $\mathrm{Cu}$ K-edge when the sample has been discharged to point $\mathrm{b}(\mathrm{Li} 2.0)$. According to the in situ PXRD measurements, less than half the $\mathrm{Cu}$ has been extruded as the element at that point, so the $\mathrm{Cu}$ edge spectrum will have contributions from elemental $\mathrm{Cu}$ and $\mathrm{Cu}^{+}$in the oxysulfide phase, consistent with the broadening of the first derivative of the XANES spectrum at point $\mathrm{b}$. Beyond $2 \mathrm{Li}$, the $\mathrm{Cu}$ edge more noticeably shifts to a lower energy (Figure S5) until the end of the discharge (point $\mathrm{d}$ ) as $\mathrm{Cu}^{+}$is reduced and the metal is completely extruded.

These XANES results and the in situ PXRD results rule out a model in which all the vacant tetrahedral sites in the sulfide layers are filled prior to any $\mathrm{Cu}$ extrusion. The insertion of 0.5 moles of $\mathrm{Li}$ to fill all these sites would be sufficient to reduce $\mathrm{Mn}$ all the way to the +2 state. However, Mn reduction persists at least up to the point at which 2 moles of Li per Mn ion have been inserted. The initial process at $2.2 \mathrm{~V}$ (Figure 2b) corresponding to approximately $0.1 \mathrm{Li}$ is nonetheless likely to be associated with $\mathrm{Li}$ insertion only into the vacancies (as discussed below). 
Table 1. Refined Lattice Parameters, Compositions, and Phase Fractions for Ex Situ PXRD Refinements

\begin{tabular}{|c|c|c|c|c|c|c|c|}
\hline Sample & $\begin{array}{l}\text { Oxysulp } \\
\text { hide } \\
\text { Phases } \\
\text { present }\end{array}$ & $a / \AA$ & $c / \AA$ & $V / \AA^{3}$ & $\begin{array}{l}\text { Oxysulfide Composition } \\
\text { (phase percentage) }\end{array}$ & $\begin{array}{l}\text { Mean } \\
\text { Composition }\end{array}$ & $\begin{array}{l}\text { Moles } \\
\text { elementa } \\
1 \mathrm{Cu} \text { per } \\
\mathrm{MnOS}: \\
\mathrm{Cu}\end{array}$ \\
\hline $\begin{array}{l}\text { Pristine } \\
\mathrm{Sr}_{2} \mathrm{MnO}_{2} \mathrm{Cu}_{3.5} \mathrm{~S}_{3}\end{array}$ & & $4.01554(3)$ & $11.4052(1)$ & $183.904(4)$ & & $\mathrm{Cu}_{3.5}$ & \\
\hline $\begin{array}{l}\text { Discharge 1.1V } \\
\text { (point d) }\end{array}$ & OS-I & $4.0149(1)$ & $11.728(2)$ & $189.05(3)$ & $\mathrm{Sr}_{2} \mathrm{MnO}_{2} \mathrm{Cu}_{0.4(1)} \mathrm{Li}_{3.6(1)} \mathrm{S}_{3}$ & $\mathrm{Cu}_{0.4(1)} \mathrm{Li}_{3.6(1)}$ & $2.9(1)$ \\
\hline \multirow{2}{*}{ Charge $2.2 \mathrm{~V}$} & OS-I & $4.0140(2)$ & $11.7324(8)$ & $189.04(3)$ & $\mathrm{Sr}_{2} \mathrm{MnO}_{2} \mathrm{Cu}_{0.4(1)} \mathrm{Li}_{3.6(1)} \mathrm{S}_{3}(33)$ & \multirow{2}{*}{${ }^{a} \mathrm{Cu}_{1.6(2)} \mathrm{Li}_{2.2(2)}$} & \multirow{2}{*}{$1.8(2)$} \\
\hline & OS-II & $4.0114(3)$ & $11.545(1)$ & $185.78(4)$ & ${ }^{a} \mathrm{Sr}_{2} \mathrm{MnO}_{2} \mathrm{Cu}_{2.2(2)} \mathrm{Li}_{1.5(2)} \mathrm{S}_{3}(66)$ & & \\
\hline \multirow{2}{*}{$\begin{array}{l}\text { Charge } 2.8 \mathrm{~V} \\
\text { (point g) }\end{array}$} & OS-II & $4.0074(5)$ & $11.350(2)$ & $182.28(7)$ & ${ }^{b} \mathrm{Sr}_{2} \mathrm{MnO}_{2} \mathrm{Cu}_{2.5(2)} \mathrm{Li}_{0.6(2)} \mathrm{S}_{3}(80)$ & \multirow{2}{*}{${ }^{a} \mathrm{Cu}_{2.0(2)} \mathrm{Li}_{0.5(2)}$} & \multirow{2}{*}{$1.7(2)$} \\
\hline & OS-III & $4.020(2)$ & $9.783(6)$ & $158.1(2)$ & ${ }^{\prime} \mathrm{Sr}_{2} \mathrm{MnO}_{2} \mathrm{~S}_{3}(20)$ & & \\
\hline $\begin{array}{l}\text { Charge } 3.7 \mathrm{~V} \\
\text { (point i) }\end{array}$ & & $4.0088(1)$ & $11.3947(5)$ & $183.12(2)$ & $\mathrm{Sr}_{2} \mathrm{MnO}_{2} \mathrm{Cu}_{3.5} \mathrm{~S}_{3}(100)$ & $\mathrm{Cu}_{3.5(2)}$ & 0 \\
\hline \multirow{2}{*}{$\begin{array}{l}{ }^{d} \text { Second discharge } \\
2.2 \mathrm{~V}\end{array}$} & OS-I & $4.0130(3)$ & $11.695(2)$ & $188.33(4)$ & $\mathrm{Sr}_{2} \mathrm{MnO}_{2} \mathrm{Li}_{4} \mathrm{~S}_{3}(25)$ & \multirow{2}{*}{$\mathrm{Cu}_{1.9(2)} \mathrm{Li}_{2.0(2)}$} & \multirow{2}{*}{$1.6(2)$} \\
\hline & OS-II & $4.0126(3)$ & $11.491(1)$ & $185.03(4)$ & $\mathrm{Sr}_{2} \mathrm{MnO}_{2} \mathrm{Cu}_{2.5} \mathrm{Li}_{1.5} \mathrm{~S}_{3}(75)$ & & \\
\hline \multirow{2}{*}{$\begin{array}{l}{ }^{d} \text { Second discharge } \\
1.1 \mathrm{~V}\end{array}$} & OS-I & $4.0168(3)$ & $11.752(1)$ & $189.61(4)$ & $\mathrm{Sr}_{2} \mathrm{MnO}_{2} \mathrm{Li}_{4} \mathrm{~S}_{3}(50)$ & \multirow{2}{*}{$\mathrm{Cu}_{1.2(2)} \mathrm{Li}_{2.7(2)}$} & \multirow{2}{*}{$2.3(2)$} \\
\hline & OS-II & $4.0058(6)$ & $11.630(2)$ & $186.62(7)$ & $\mathrm{Sr}_{2} \mathrm{MnO}_{2} \mathrm{Cu}_{2.5} \mathrm{Li}_{1.5} \mathrm{~S}_{3}(50)$ & & \\
\hline
\end{tabular}

${ }^{a}$ Overall Li content deduced from point on charge profile. ${ }^{b}$ OS-II phase assumed to contain remaining Li. ${ }^{c}$ Poorly characterized minority phase.

${ }^{d}$ Second discharge after charging to $2.8 \mathrm{~V}$.

Two different environments exist for $\mathrm{S}$ in the structure. Onethird of the $S$ atoms lie in the center of the sulfide layers directly coordinated only to $\mathrm{Cu}$ (and/or $\mathrm{Li}$ ). The other twothirds of the $\mathrm{S}$ atoms are coordinated to both $\mathrm{Cu} / \mathrm{Li}$ and $\mathrm{Mn}$. The XANES spectra at the $S$ K-edge (Figure 8) contain contributions from both species. The lowest energy shoulder I at $2471 \mathrm{eV}$ is assigned to transitions of the $\mathrm{S} 1$ s electrons to transition metal-3d/S-3p states, whereas the features at higher energies (II-IV) are associated with mixed states involving metal $4 \mathrm{~s}$ and $4 \mathrm{p} .{ }^{36,37}$ Upon lithiation, the intensity of the peak II absorption (at $2475 \mathrm{eV}$ ) decreases while that of IV (2482 $\mathrm{eV}$ ) increases. Similar changes in intensity have been observed earlier for $\mathrm{Li}_{x} \mathrm{TiS}_{2}{ }^{36}$ Computational simulations have concluded that these changes could be primarily by an elongation of the $\mathrm{Ti}-\mathrm{S}$ bond during reduction, together with a decrease of the empty states available for excitation of $S 1$ s electrons due to the introduction of electrons during the reduction process. A $5.5 \%$ elongation of the $\mathrm{Mn}-\mathrm{S}$ bond resulting from the chemical lithiation of $\mathrm{MnCu}(\mathrm{II})$ has earlier been reported. In the present study, insertion of $\mathrm{Li}$ into $\mathrm{MnCu}(\mathrm{II})$ produces a change in the chemical bonding between $S$ and its surrounding cations; however, the $\mathrm{S} \mathrm{K}$ edge XANES data are consistent with the absence of major crystal structural reorganizations, with most changes occurring in the electronic structure, especially near the Fermi level.

In addition to these changes, a new peak at $2477 \mathrm{eV}$ (III) emerges during discharge, which resembles the signals reported for anti-fluorite-type $\mathrm{Li}_{2} \mathrm{~S},{ }^{34,36}$ consistent with the formation of $\mathrm{a} \mathrm{Li}_{4} \mathrm{~S}_{3}$ anti-fluorite-type slab. Given their similar ionic radii, ${ }^{35}$ the substitution of $\mathrm{Cu}^{+}$by $\mathrm{Li}^{+}$is not expected to introduce substantial structural changes, but the ionic character of the bonding within the antifluorite slabs will change. ${ }^{36}$

3.3.2. First Charge. The normalized Mn K-edge XANES spectra of different states of charge of $\mathrm{MnCu}$ (II) are shown in Figure 9. On charging from the fully lithiated sample (point $\mathrm{d}$ in the voltage profile in Figure 2) to the end of the $1.8 \mathrm{~V}$ process (point e), the absorption edge clearly shifts to higher energy (associated with a significant change of the line shape), 


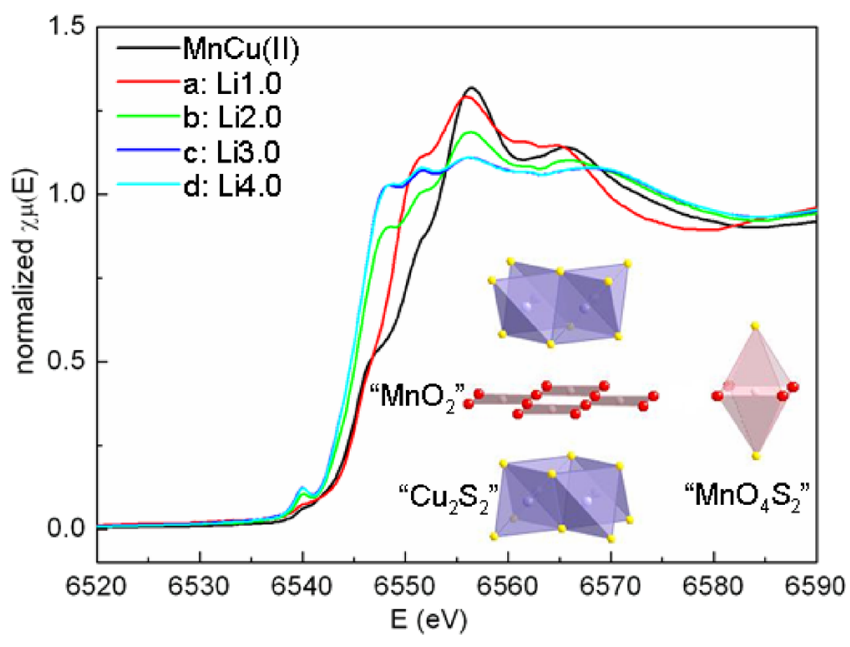

Figure 7. Normalized Mn K-edge XANES spectra of pristine and lithiated $\mathrm{MnCu}(\mathrm{II})$ phases during the first discharge. The inset shows the distorted octahedral environment around $\mathrm{Mn}$ (represented as " $\mathrm{MnO}_{4} \mathrm{~S}_{2}$ " in the figure) ( $\mathrm{Sr}$ ions are omitted for clarity).

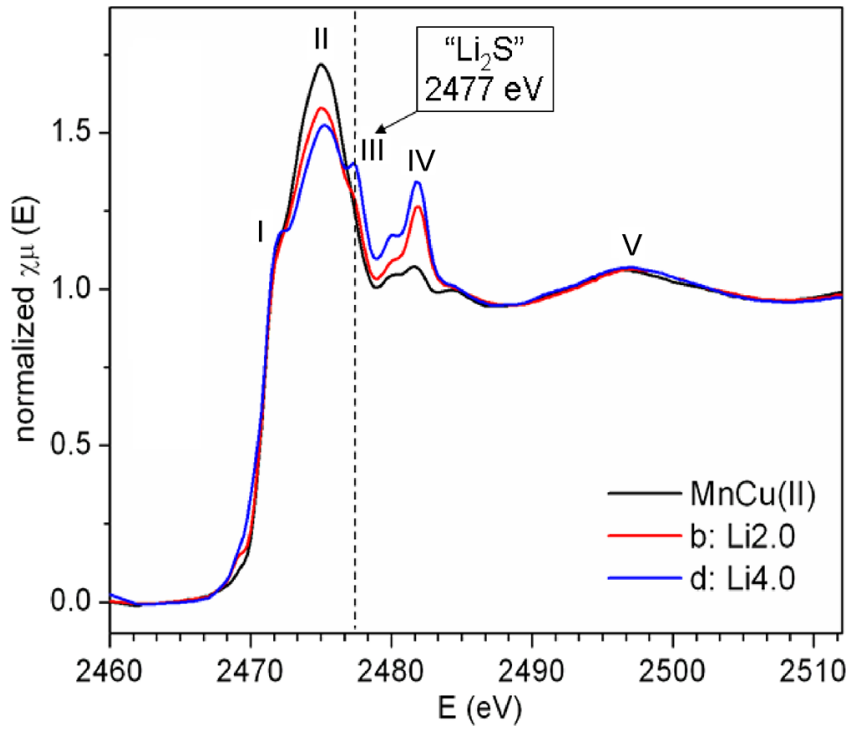

Figure 8. Normalized S K-edge XANES spectra of pristine and lithiated $\mathrm{MnCu}(\mathrm{II})$ phases during the first discharge. The absorption features are labeled with numbers I-V. The energy of feature III (ascribed to sulfur in a $\mathrm{Li}_{2} \mathrm{~S}$-like, anti-fluorite arrangement) is indicated with a dashed line.

indicating the oxidation of $\mathrm{Mn}$ during the $1.8 \mathrm{~V}$ process upon $\mathrm{Li}$ removal, which is not fully compensated by the intercalation of $\mathrm{Cu}$. Charging further to the start of the $2.5 \mathrm{~V}$ process (point f), the absorption edge of $\mathrm{Mn}$ slightly shifts back to lower energy. This re-reduction of $M n$ between point $e$ and $f$ coincides with the in situ PXRD observations of a sharp increase in the overall content of the Cu-rich OS-II phase at the expense of OS-I and a fairly rapid decrease in the weight fraction of elemental $\mathrm{Cu}$ in the sample. However, from the fully lithiated sample $d$ to sample $f$, there is only a small net shift of the $\mathrm{Mn}$ absorption edge. On further charging, there is a large shift in the position of the $\mathrm{Mn}$ edge to higher energies during the $2.5 \mathrm{~V}$ process (point $\mathrm{f}$ to point $\mathrm{g}$ ).

The PXRD and NPD results show that there is little change in the amount of elemental $\mathrm{Cu}$ in this region and $\mathrm{Li}$ deintercalation is not accompanied by $\mathrm{Cu}^{+}$ion insertion into the oxysulfide. Correspondingly, the XANES results show that $\mathrm{Li}$ deintercalation during the $2.5 \mathrm{~V}$ charging plateau is accompanied by $\mathrm{Mn}$ oxidation, also consistent with the decrease in unit cell volume in the diffraction data. On charging up to $3.75 \mathrm{~V}$ (point $\mathrm{i}$ ), the final spectrum is nearly similar to that of $\mathrm{MnCu}$ (II) (Figure 9b), indicating that delithiation from the structure and the re-insertion of $\mathrm{Cu}$ largely restores both the oxidation state and the environment surrounding $\mathrm{Mn}$, consistent with the diffraction results.

No significant change in $\mathrm{Cu}$ K-edge position on charging from the fully discharged state (sample d) up to the onset of the $2.5 \mathrm{~V}$ process (sample f) was observed (Figure S6). However, charging to $2.75 \mathrm{~V}$ (sample g) and $3.75 \mathrm{~V}$ (sample i) induces a continuous but small shift of the $\mathrm{Cu}$ K-edge to a higher energy to a position close to that of $\mathrm{MnCu}$ (II). This final insertion of $\mathrm{Cu}$ into the oxysulfide occurs at a significant overpotential (see Figure S1) and also at a higher oxidation potential than standard $\mathrm{Cu} / \mathrm{Cu}^{+}$oxidation vs $\mathrm{Li} / \mathrm{Li}^{+}(3.56 \mathrm{~V})$.

Figure S7 shows the S K-edge XANES spectra for samples obtained during the first charge. Feature III, characteristic of sulfide in an antifluorite $\mathrm{Li}_{2} \mathrm{~S}$-like environment, decreases in intensity (Figure S7a, inset) during both the 1.8 and $2.5 \mathrm{~V}$ processes and is not visible at $2.75 \mathrm{~V}$ (sample $\mathrm{g}$ ), suggesting that a large amount of $\mathrm{Li}$ has been removed. The process at 2.5 $\mathrm{V}$ (i.e., sample $\mathrm{f}$ to sample $\mathrm{g}$ ) involves an increase in the intensity of feature II, presumably arising from the shortening of the $\mathrm{Mn}-\mathrm{S}$ bonds resulting from the oxidation of $\mathrm{Mn}$. The absorption spectra for samples $g$ and $i$ are similar to each other, but they exhibit clear differences from the spectrum of pristine $\mathrm{MnCu}(\mathrm{II})$ (Figure S7b), suggesting that the $\mathrm{Cu}-\mathrm{S}$ bonding as well as the sulfur environments are not entirely restored to that of the pristine material even when the battery was charged to $3.75 \mathrm{~V}$. Besides the intensity differences of features II and IV, a new absorption at around $2470 \mathrm{eV}$ is present for both samples $\mathrm{g}$ and $\mathrm{i}$ (inset in Figure S7b). The appearance of a peak at a similar energy has earlier been ascribed to the partial oxidation of $S^{2-}$ to $S^{2-n}(0<n<1)$ for $\mathrm{NaCrS}_{2}{ }^{38}$ and $\mathrm{Li}_{2} \mathrm{FeS}_{2} .{ }^{39}$ This sulfur oxidation (likely coupled with $\mathrm{Mn}$ oxidation) may help stabilize the cation-deficient OS-III phase formed during the $2.5 \mathrm{~V}$ charging process.

3.3.3. Second Discharge. The voltage profile during the second discharge varies depending on the cutoff voltage applied for the first charge $(2.75$ or $3.75 \mathrm{~V})$. The Mn K-edge XANES spectra obtained during the second discharge after charging to $3.75 \mathrm{~V}$ (Figure $10 \mathrm{a}$ ) resemble those obtained during the first discharge of the pristine oxysulfide with $\mathrm{Mn}$ fully reduced, as could be expected from the similar electrochemical signatures observed during both cycles. When the cutoff voltage applied to the first charge is $2.75 \mathrm{~V}$, the Mn XANES results clearly show that the absorption edge moves to lower energy only from sample $g$ to 1 but stays at the same position thereafter (Figure 10b). This suggests that $\mathrm{Mn}$ reduction takes place mostly during the $2.2 \mathrm{~V}$ process (sample g).

The $\mathrm{Cu}$ K-edge XANES data shows when the battery is charged to $3.75 \mathrm{~V}$, the behavior on discharge is similar to that of the first discharge i.e., $\mathrm{Cu}$ reduction is not evident when discharging the battery to $1.5 \mathrm{~V} \mathrm{(ca.} 1.0 \mathrm{Li}$ inserted, sample j, Figure S8). When the first charge is to $2.75 \mathrm{~V}$, distinct plateaus are found at 2.2 and $1.5 \mathrm{~V}$ on the subsequent discharge, with continuous $\mathrm{Cu}$ reduction observed throughout (Figure S8).

Figure S9 compares the S K-edge XANES spectra during the second discharge for materials charged to either 3.75 or $2.75 \mathrm{~V}$. 

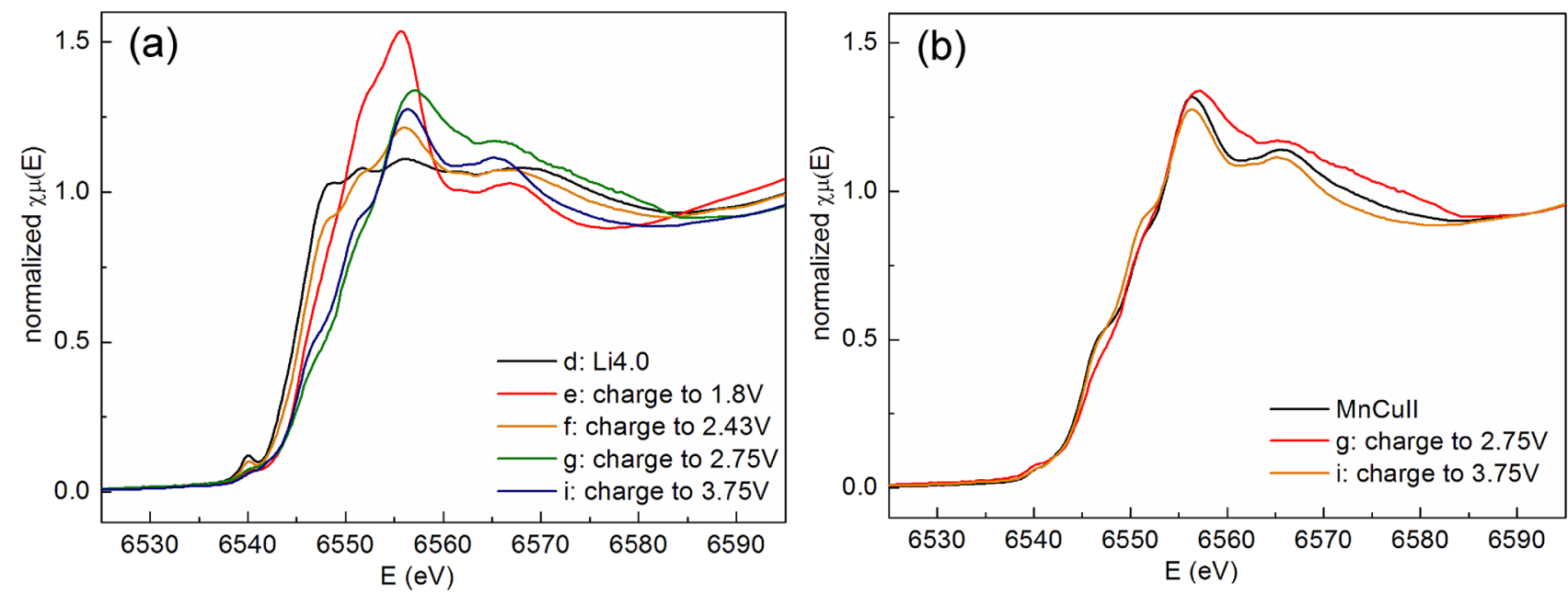

Figure 9. Normalized $\mathrm{Mn}$ K-edge XANES spectra of (a) lithiated $\mathrm{MnCu}(\mathrm{II})$ phases during the first charge and (b) $\mathrm{MnCu}(\mathrm{II})$ along with samples at points $g$ and $i$.
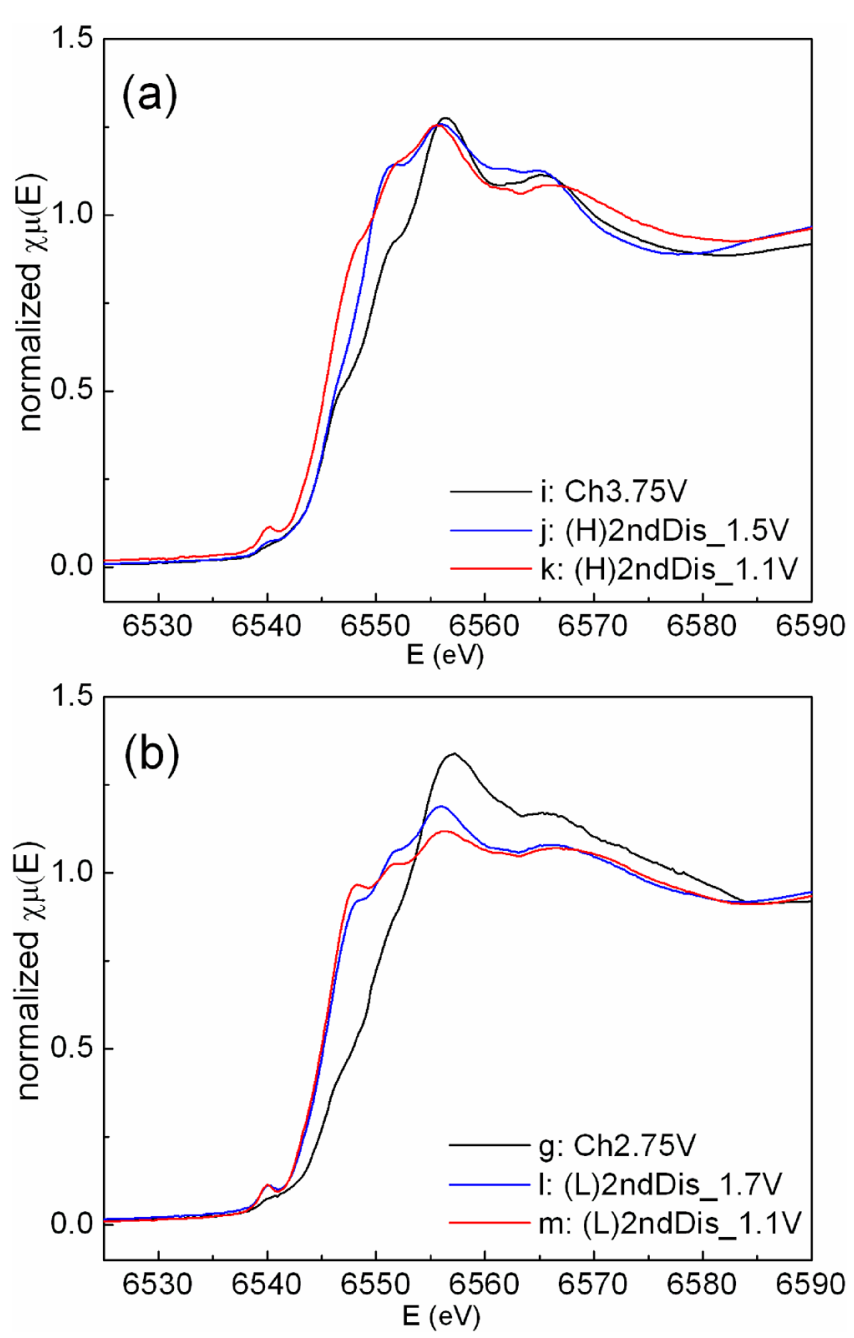

Figure 10. Normalized $\mathrm{Mn}$ K-edge XANES spectra of $\mathrm{MnCu}(\mathrm{II})$ phases during the two second discharge processes after the first charge. The cutoff voltage of the first charge is (a) $3.75 \mathrm{~V}$ and (b) $2.75 \mathrm{~V}$.

While similar features are observed in the two cases, comparison of points obtained during the discharges shows that the $S$ atoms undergo greater changes during the second discharge after being charged to $3.75 \mathrm{~V}$ than after a $2.75 \mathrm{~V}$ charge.

3.4. ${ }^{7} \mathrm{Li}$ NMR Results. The ex situ ${ }^{7} \mathrm{Li}$ NMR spectra for different samples recovered during the first discharge and charge are shown Figure 11. Besides an intense resonance at 0 ppm, which arises from diamagnetic impurities/electrolyte decomposition products, all the spectra show a group of resonances between 200 and $270 \mathrm{ppm}$, the shift resulting from the Fermi contact interaction between paramagnetic $\mathrm{Mn}$ and $\mathrm{Li}$ ions, mediated through the $\mathrm{S}$ bonds via a similar mechanism to that seen in lithium manganese oxides. ${ }^{40}$

During the first discharge, the spectrum of sample Li1.0 (sample a in Figure 2b) shows two distinct resonances at 210 and $265 \mathrm{ppm}$, and upon further Li intercalation, only the former remains in the spectra of samples Li2.0 (b), Li3.0 (c), and $\mathrm{Li} 4.0$ (d). The intensity of the $210 \mathrm{ppm}$ resonance increases with $\mathrm{Li}$ content. $\mathrm{Li}$ is located in the tetrahedral sites within the antifluorite-type layer and interacts with two Mn ions in the oxide layer via $\mathrm{Mn}-\mathrm{S}-\mathrm{Li}$ interactions. Previous $\mathrm{Mn}$ K-edge XANES, magnetic susceptibility and bond valence sum data revealed a mean oxidation state of $\mathrm{Mn}^{2.5+}$ in the pristine phase. $^{20} \mathrm{Mn}$ ions are coupled ferromagnetically within the $\mathrm{MnO}_{2}$ planes and magnetic long-range order occurs below about $50 \mathrm{~K}$. This ferromagnetism, which arises either from superexchange between charge-ordered $\mathrm{Mn}^{2+}$ and $\mathrm{Mn}^{3+}$ ions or from itinerant $d_{x^{2}-y^{2}}$ electrons, is further evidence for the mixed valence of $\mathrm{Mn}$. As $\mathrm{Li}$ is inserted into the framework, the XANES results indicate that full reduction to $\mathrm{Mn}^{2+}$ is obtained in sample Li2.0 (b). Therefore, the $210 \mathrm{ppm}$ resonance has been assigned to $\mathrm{Li}$ interacting with only $\mathrm{Mn}^{2+}$ (two $\mathrm{Li}-\mathrm{S}-$ $\mathrm{Mn}^{2+}$ interactions) and the $265 \mathrm{ppm}$ resonance has been assigned to a $\mathrm{Li}$ environment containing $\mathrm{Mn}^{3+}$ (one $\mathrm{Li}-\mathrm{S}-$ $\mathrm{Mn}^{3+}$ interaction and one $\mathrm{Li}-\mathrm{S}-\mathrm{Mn}^{2+}$ interaction). An environment with $\mathrm{Li}$ interacting with two $\mathrm{Mn}^{3+}$ ions is unlikely. First, this configuration is not energetically favorable due to the larger Coulombic repulsion between two more highly charged $\mathrm{Mn}^{3+}$ cations. Second, the amount of $\mathrm{Mn}^{3+}$ is very small after insertion of $1 \mathrm{~mol} \mathrm{Li}$. Since the NMR shifts are additive, it can be deduced that each $\mathrm{Li}-\mathrm{S}-\mathrm{Mn}^{2+}$ interaction results in approximately a $210 / 2=105 \mathrm{ppm}$ shift in the ${ }^{7} \mathrm{Li}$ NMR spectrum and each $\mathrm{Li}-\mathrm{S}-\mathrm{Mn}^{3+}$ induces around a $265-$ $105=160 \mathrm{ppm}$ shift. The value for the $\mathrm{Li}-\mathrm{S}-\mathrm{Mn}^{2+}$ interaction is consistent with the shifts observed for the other lithiated 


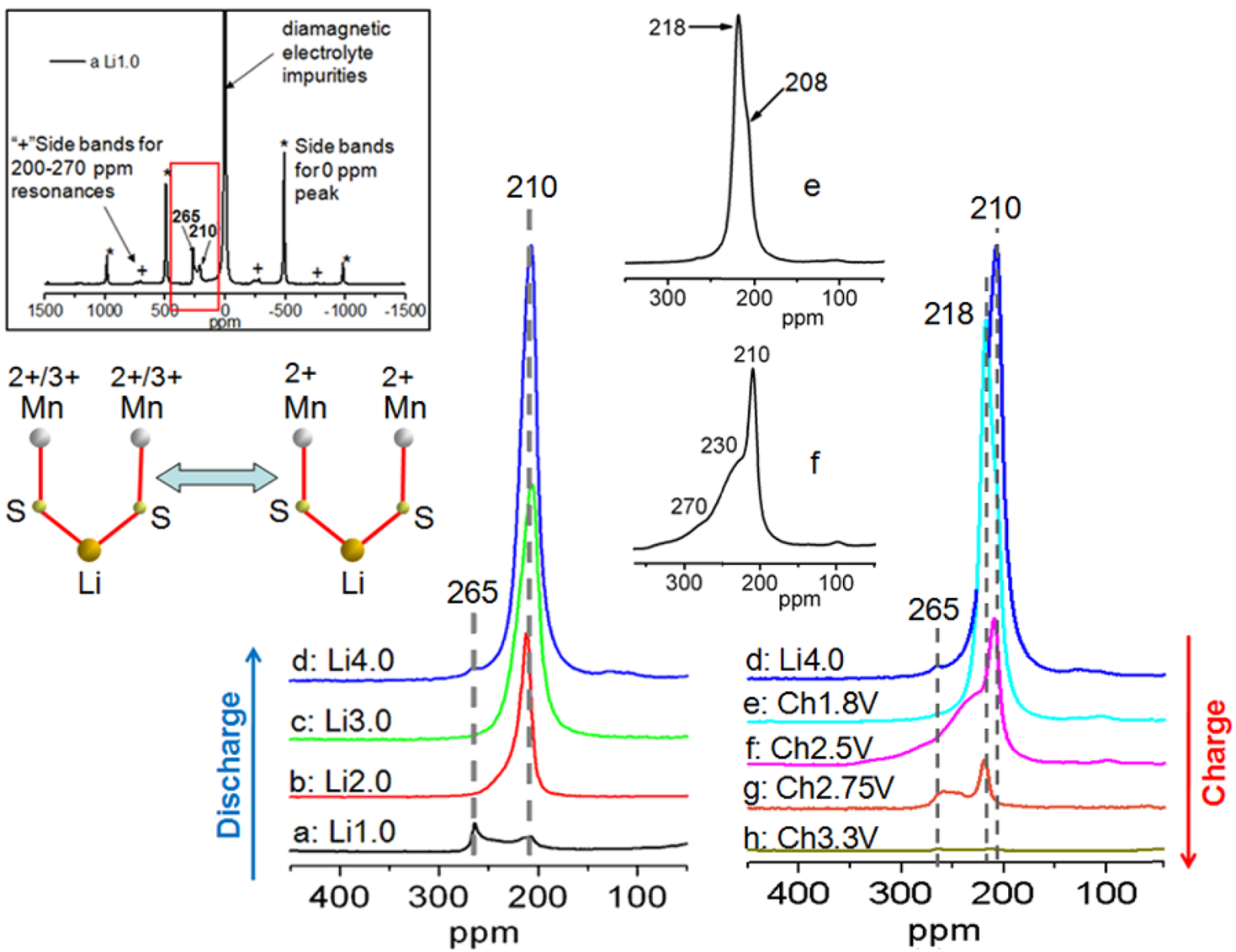

Figure 11. Zoom-in view of the ${ }^{7} \mathrm{Li}$ NMR spectra of $\mathrm{MnCu}$ (II) during the first discharge (left) and charge (right). The spectra have been normalized based on the acquisition number and sample mass. The inset on the top left corner is the full spectrum of sample a: Lil.0 shown as an example. The zoomed region is indicated by a red rectangular box. The spectra of samples e and $\mathrm{f}$ within the 50-350 ppm region are shown separately in the middle inset. A schematic picture showing the $\mathrm{Li}$ environments in the $\mathrm{MnCu}$ (II) structure during the discharge/charge cycle is also included (left lower part).

oxysulfides in the same series as $\mathrm{MnCu}(\mathrm{II}){ }^{22}$ The $\mathrm{Li}$ Fermi contact shifts in paramagnetic materials are usually proportional to the unpaired electron density transferred from the paramagnetic species. In the axially elongated $\mathrm{MnO}_{4} \mathrm{~S}_{2}$ octahedra the electronic configurations are as follows: $\mathrm{Mn}^{2+}$ : $\left(\mathrm{d}_{x z}\right)^{1},\left(\mathrm{~d}_{y z}\right)^{1}\left(\mathrm{~d}_{x y}\right)^{1}\left(\mathrm{~d}_{z^{2}}\right)^{1}\left(\mathrm{~d}_{x^{2}-y^{2}}\right)^{1}$ and $\mathrm{Mn}^{3+}:\left(\mathrm{d}_{x z}\right)^{1}$, $\left(\mathrm{d}_{y z}\right)^{1}\left(\mathrm{~d}_{x y}\right)^{1}\left(\mathrm{~d}_{z^{2}}\right)^{1}\left(\mathrm{~d}_{x^{2}}-y^{2}\right)^{0}$. The electron counts only differ in the $\mathrm{d}_{x^{2}}-y^{2}$ orbitals, which cannot participate in the $\mathrm{Mn}-\mathrm{S}-\mathrm{Li}$ interactions. Therefore, the larger shift for contacts with $\mathrm{Mn}^{3+}$ seems to simply be a consequence of the greater covalency of the $\mathrm{Mn}-\mathrm{S}$ interaction than in the $\mathrm{Mn}^{2+}$ case.

The signal at $210 \mathrm{ppm}$ comes from the OS-I phase, the only Li-containing oxysulfide present in Li4.0 (d). During the charge, from sample $d$ to $e$, an intense resonance appears at around $218 \mathrm{ppm}$ (Figure 11), the shift likely arising from the increase in the oxidation state of $\mathrm{Mn}$ in the structure. Upon further charging to $2.5 \mathrm{~V}$ (f), the $210 \mathrm{ppm}$ signal recovers, indicating the restoration of some $\mathrm{Mn}^{2+}$ environments nearby to $\mathrm{Li}$, and broad shoulders at higher chemical shifts (centered at 230 and $270 \mathrm{ppm}$ ) appear. These are consistent with the $\mathrm{Mn}$ XANES results (see Figure 9a), which indicate oxidation of $\mathrm{Mn}$ during initial charging to $1.8 \mathrm{~V}$ and then partial reduction of $\mathrm{Mn}$ as the charging is continued to $2.50 \mathrm{~V}(\mathrm{f})$. In situ PXRD results show the OS-II phase appears during $1.8 \mathrm{~V}$ charging, accounting for the appearance of $218 \mathrm{ppm}$ resonance at point e. When the battery is charged further to $2.75 \mathrm{~V}$ (sample g), the spectrum shows a low intensity resonance at $218 \mathrm{ppm}$ and a further broad resonance feature centered around $250 \mathrm{ppm}$, consistent with the oxidation of $\mathrm{Mn}$ as clearly observed in $\mathrm{Mn}$ XANES. The $210 \mathrm{ppm}$ resonance is absent at point $\mathrm{g}$, congruous with the diffraction findings that no more OS-I is present at this point.

The higher $\mathrm{ppm}$ resonances are assigned to $\mathrm{Li}$ in environments containing both $\mathrm{Mn}^{3+}$ and $\mathrm{Mn}^{2+}$. The broad lines evident on charging from point $\mathrm{e}$ to point $\mathrm{g}$ suggest that $\mathrm{Li}$ is distributed over environments where a continuous range of bond lengths $(\mathrm{Mn}-\mathrm{S}$ and $\mathrm{S}-\mathrm{Li})$, bond angles $(\mathrm{Li}-\mathrm{S}-\mathrm{Mn})$, and $\mathrm{Mn}$ oxidation states are present, resulting in a continuous distribution of the shifts. The diffraction results show that two phases are present in this region, and although the precise distribution of Li between these phases cannot be quantified by analysis of our diffraction measurements, it is likely that both OS-I and OS-II phases contain some Li over much of this 2.5 $\mathrm{V}$ process, with the third phase observed at the very top of charge not containing any Li. Clearly, the presence of $\mathrm{Li}$ in at least two phases contributes to there being a wide range of environments.

The resonances in the spectra of the samples charged to 3.3 V (sample h) and $3.75 \mathrm{~V}$ (see Figure 12, sample i) have only a very weak resonance at $265 \mathrm{ppm}$, indicating that only a small amount of Li remains in the structure at this stage and that the $\mathrm{Mn}+2.5$ state has been restored. Consistent with this, the $S$ XANES results show that the environment resembling that in $\mathrm{Li}_{2} \mathrm{~S}$ is not observed in samples charged to higher than $2.75 \mathrm{~V}$, 


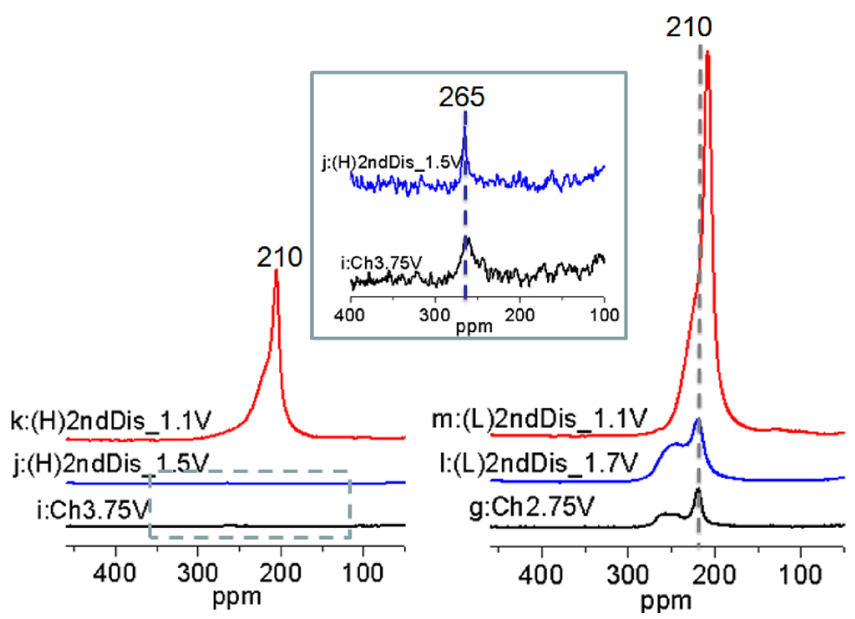

Figure 12. ${ }^{7} \mathrm{Li}$ NMR spectra of $\mathrm{MnCu}(\mathrm{II})$ during the second discharge after charging to $3.75 \mathrm{~V}$ (left) and $2.75 \mathrm{~V}$ (right). The spectra have been normalized based on the acquisition number and sample mass, and the two groups of spectra are shown at the same scale. The inset shows an expansion of the spectra of samples $i$ and $j$ (indicated by a gray rectangle box in the left) 20 times amplified in magnitude.

and the NPD result on sample i shows that a composition close to $\mathrm{Sr}_{2} \mathrm{MnO}_{2} \mathrm{Cu}_{3.5} \mathrm{~S}_{3}$ is restored.

The ${ }^{7} \mathrm{Li}$ NMR results for samples during the two second discharge processes are shown in Figure 12 (N.B.: the small displacement of the shift in the spectrum for sample $\mathrm{m}$ is not intrinsic but very likely caused by the small temperature variations between the MAS experiment). It is clear that the spectral intensity of the samples following a charge to $3.75 \mathrm{~V}$ is significantly lower than those where the cutoff voltage was set to $2.75 \mathrm{~V}$. This is consistent with the electrochemical profiles shown in Figure 2, where the Li equivalents in samples $\mathrm{j}$ and $\mathrm{k}$ are smaller than in samples 1 and $\mathrm{m}$. Despite the intensity difference, the spectra of the two samples at the end of each discharge (samples $\mathrm{k}$ and $\mathrm{m}$ ) have very similar line shapes: an intense resonance at around $210 \mathrm{ppm}$ with a shoulder at a higher frequency. This observation contrasts with the symmetric resonance at $210 \mathrm{ppm}$ observed for the sample at the end of the first discharge (sample d: Li4.0). It further confirms that the reduction of the material does not appear to be as efficient after the first cycle, as discussed above in the context of the PXRD data (Table 1).

\section{DISCUSSION}

The redox reactions and phase transitions occurring during the first discharge and charge cycle of a Li battery containing $\mathrm{MnCu}$ (II), as deduced from our results, are summarized in Figure 13. The pristine $\mathrm{MnCu}(\mathrm{II})$ structure is composed of rigid perovskite-type oxide $\left(\mathrm{Sr}_{2} \mathrm{MnO}_{2}\right)$ layers and relatively flexible antifluorite-type sulfide layers $\left(\mathrm{Cu}_{4-\delta} \mathrm{S}_{3}\right)$. The thermodynamically stable composition obtained in conventional high temperature solid-state synthesis has $\mathrm{Mn}$ in an oxidation state of +2.5 , and there are a corresponding number of $\mathrm{Cu}$ vacancies in the sulfide layer $(\delta \approx 0.5)$. The oxide and sulfide layers are commensurate with one another so the $S-S$ separation within the basal plane of the sulfide layer, and the $\mathrm{Mn}-\mathrm{Mn}$ distance within the oxide layer are both equal to the basal lattice parameter, $a$ of $4.015 \AA$ (which is also double the $\mathrm{Mn}-\mathrm{O}$ bond length $(2.0076 \AA)){ }^{22}$ This $\mathrm{S}-\mathrm{S}$ distance is slightly longer than the $\mathrm{S}-\mathrm{S}$ distance in antifluorite $\mathrm{Cu}_{2} \mathrm{~S}$ of
$3.94 \AA{ }^{41}$ so the tetrahedral sites are larger in $\mathrm{MnCu}(\mathrm{II})$ and the $\mathrm{Cu}$ ions are highly disordered over the tetrahedral sites and neighboring trigonal sites, likely associated with considerable mobility of $\mathrm{Cu}$.

When $\mathrm{Li}$ is inserted into the structure, on first discharging the cell, there is a short process at $2.2 \mathrm{~V}$ in the electrochemical profile (step 1, Figure 13), ascribed to the insertion of $0.1 \mathrm{Li}$ per $\mathrm{Mn}$ into the vacant sites in the sulfide layer (i.e., sufficient to fill only $20 \%$ of the vacant tetrahedral sites). During the following long gently sloping (approximately) $1.7 \mathrm{~V}$ process, $\mathrm{Mn}$ is reduced to $\mathrm{Mn}^{2+}$ as $\mathrm{Li}$ fills the remaining vacancies and also displaces elemental copper; the XANES and in situ PXRD results show that these processes occur concurrently up until about halfway through the discharge (step 2) at which point the XANES results show that Mn is fully reduced. The PXRD results show that copper extrusion continues until the system is fully discharged. During this $1.7 \mathrm{~V}$ process a single oxysulfide phase, OS-I is observed, indicating a continuous change of the parameters of the framework as lithium is inserted and copper is extruded. At the end of the discharge, the basal lattice parameter increases sharply (Figure 4a) as the OS-I phase becomes fully lithiated $\mathrm{Sr}_{2} \mathrm{MnO}_{2} \mathrm{Li}_{4} \mathrm{~S}_{3}$ with no vacancies on the tetrahedral sites in the sulfide layer (Table S2).

During the charge, the mechanism of delithiation and eventual reinsertion of $\mathrm{Cu}$ is complex. During the first process at $c$ a. $1.8 \mathrm{~V}$, only $\mathrm{Li}$ is removed, indicated by a decrease in the intensity of the $\mathrm{S}$ XANES peak corresponding to $\mathrm{Li}_{2} \mathrm{~S}$-like sulfide ions and the diminishing intensity of peaks in the ${ }^{7} \mathrm{Li}$ MAS NMR spectra. However, the PXRD results suggest that re-insertion (oxidation) of $\mathrm{Cu}$ during this process is negligible, which is ascribed, at least in part, to the sluggish migration of $\mathrm{Cu}^{+}$into and through the structure to occupy the tetrahedral sites vacated by $\mathrm{Li}^{+}$, the $\mathrm{Li}^{+}$ions being more readily removed from the structure. The shift in the Mn K-edge and the shift of the ${ }^{7} \mathrm{Li} \mathrm{NMR}$ resonance indicates that the charge compensation during the $1.8 \mathrm{~V}$ charging process comes from the oxidation of Mn. Importantly, during the $1.8 \mathrm{~V}$ process, PXRD shows the clear presence of two oxysulfide phases (end of step 5). The "step" in the charging profile between 1.8 and $2.5 \mathrm{~V}$ (point e to point $f$ ) is accompanied by a rapid change in the phase fractions of the two oxysulfide phases and by a decrease in the amount of elemental $\mathrm{Cu}$ present in the diffractograms (step 6). A slight re-reduction of $\mathrm{Mn}$, as the $\mathrm{Cu}$ is inserted into the OS-II and OS-I phases, is revealed by the behavior of the $\mathrm{Mn} \mathrm{K}$ edge and the ${ }^{7} \mathrm{Li}$ NMR resonance. The GITT data (Figure S1) indicates a large overpotential for step 6, the voltage relaxing back to close to that of step 5. It is possible that some of the $\mathrm{Cu}$ insertion occurs via a chemical process during stage 6 , resulting in the $\mathrm{Mn}$ reduction.

The process at $2.5 \mathrm{~V}$ involves the continued removal of $\mathrm{Li}$, but the NMR results show that there still exists a small amount in the structure even at $2.75 \mathrm{~V}$. During this process, the $\mathrm{Mn} \mathrm{K}$ edge undergoes a large shift to higher energies, the oxidation of $\mathrm{Mn}$ resulting in a short $\mathrm{Mn}-\mathrm{O}$ bond length as revealed by the short $a$ lattice parameter for the majority oxysulfide phase. There is very little change in the amount of $\mathrm{Cu}$ in the crystalline oxysulfide phases. The unit cell volume of the majority oxysulfide phase, OS-II, reaches a minimum toward the end of this process consistent with the formation of a new derivative of $\mathrm{Sr}_{2} \mathrm{MnO}_{2} \mathrm{Cu}_{3.5} \mathrm{~S}_{3}$ with a larger number of vacancies on the tetrahedral sites in the sulfide layers and with a higher Mn oxidation state. As the battery is charged to $2.75 \mathrm{~V}$, there is evidence in the ex situ PXRD data for a further 
Specific capacity $(\mathrm{mAh} / \mathrm{g})$

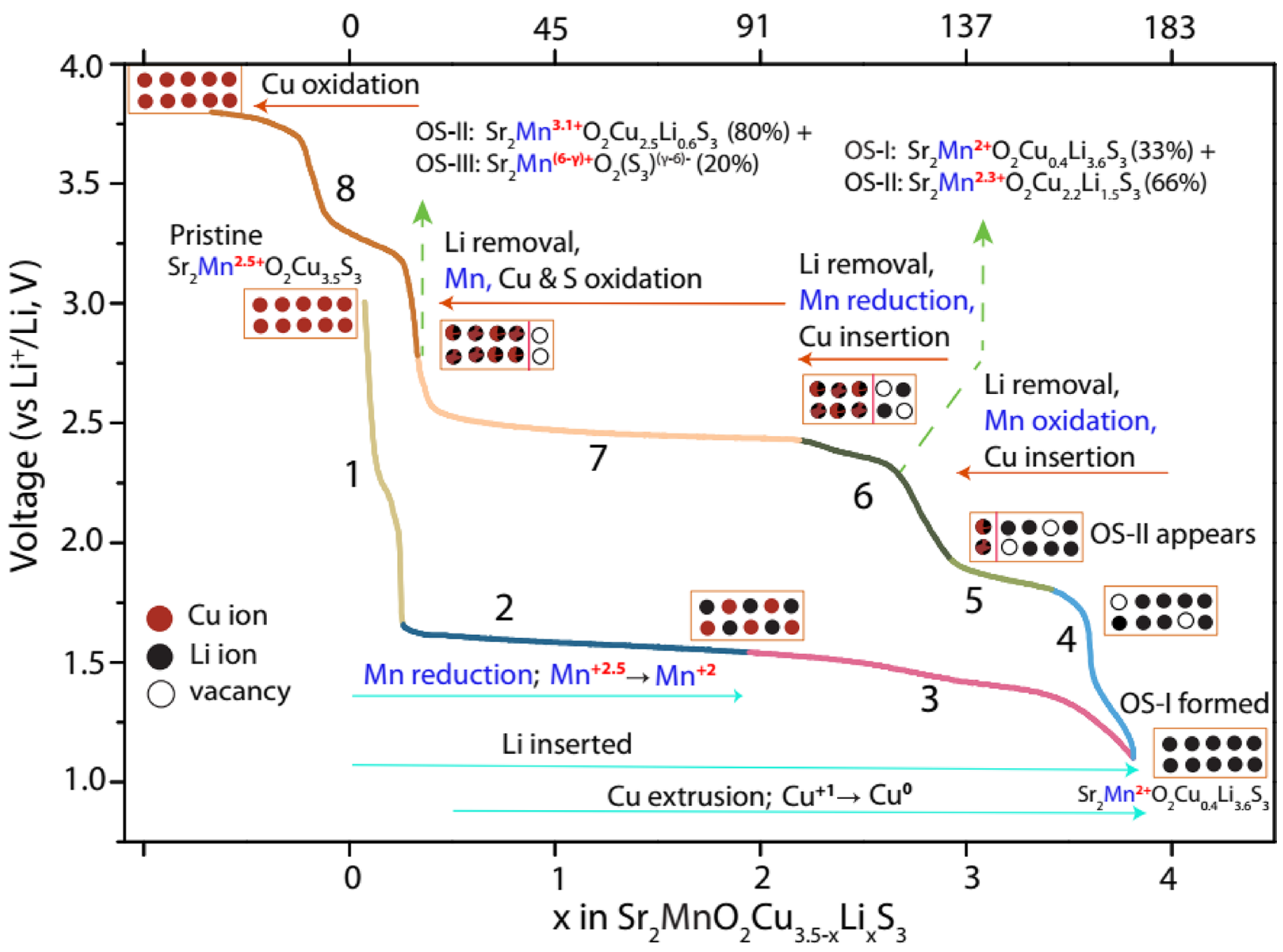

Figure 13. Summary of the redox reactions involved for each process during the first cycle of a $\mathrm{MnCu}(\mathrm{II}) \mid \mathrm{Li}$ battery within the voltage window of 1.1-3.75 V. The discharge and charge processes are labeled with cyan and red arrows, respectively. The arrow indicates the direction of voltage change. The redox changes associated to the particular voltage-capacity regime are given over each arrow. The voltage-capacity plot is divided in eight steps, each marked with different colors, to help visualize the different redox processes. The orange boxes represent model of the $\mathrm{Li} / \mathrm{Cu}$ content in the oxysulfide phases, where $\mathrm{Cu}^{+}, \mathrm{Li}^{+}$, and vacancies are shown by red, black, and unfilled balls, respectively. Mixed Cu and $\mathrm{Li}$ occupancy is illustrated by fused red/black balls. Where a red line inside the box is shown, this indicates the coexistence of two phases. This model is a simplistic representation of the insertion/extraction of $\mathrm{Cu} / \mathrm{Li}$ ions and formation of vacancies at different redox potentials. The variable $\gamma$ reflects uncertainties in the oxidation state of $\mathrm{Mn}$ and $\mathrm{S}$ of the phase OS-III, which arises as OS-III is a minority, and hence a less well-characterized phase, the composition $\mathrm{Sr}_{2} \mathrm{MnO}_{2} \mathrm{~S}_{3}$ representing the limiting one, assuming all metal ions are indeed removed from the sulfide layer.

related oxysulfide phase (OS-III), which has a greatly contracted (by 14\%) $c$ lattice parameter compared with the $\mathrm{Sr}_{2} \mathrm{MnO}_{2} \mathrm{Cu}_{3.5} \mathrm{~S}_{3}$ parent phase (end of step 7). This was only ever found as a minority phase, hampering the detailed analysis of the structure, but the large contraction of the lattice parameter normal to the layers suggests that it may be completely devoid of metal cations in the sulfide layer. Further experiments to isolate as bulk phases this phase and the other intermediate phases evident in the experiment are ongoing.

The deintercalation of large amounts of Li over the course of the long $2.5 \mathrm{~V}$ process does not appear to be compensated completely by the re-injection of $\mathrm{Cu}$, and thus oxidation of $\mathrm{Mn}$ alone is not sufficient to compensate the oxidative deintercalation of $\mathrm{Li}$ (step 7). The PXRD and NPD results at 2.75 $\mathrm{V}$ (point $\mathrm{g}$ ) confirm that the insertion of $\mathrm{Cu}$ is far from complete and the majority of the $\mathrm{Cu}$ exists in the elemental form rather than being reinserted into the oxysulfide phase, and more vacant tetrahedral sites must exist in the oxysulfide phase OS-II than are present in the pristine phase (Table S2).
It is clear that $\mathrm{Li}$ removal occurs faster than $\mathrm{Cu}$ reinsertion. The $\mathrm{Cu}$ XANES K-edge at point $\mathrm{g}$ suggests that the $\mathrm{Cu}$ is in the more oxidized state than in the pristine material. The $\mathrm{S} \mathrm{K}$ edge XANES also develops new edge features, which have been ascribed to the partial oxidation of $\mathrm{S}^{2-}$ at the end of $2.5 \mathrm{~V}$ charging. The minority phase OS-III with the contracted $c$ parameter, consistent with a lack of cations in the sulfide layers, would have a limiting composition $\mathrm{Sr}_{2} \mathrm{MnO}_{2} \mathrm{~S}_{3}$, a composition that cannot be fully accounted for by assuming $\mathrm{Mn}$ oxidation, and at least partial sulfide oxidation in this phase is consistent with the XANES data. The majority phase at this point in the charge process, OS-II has an estimated composition $\mathrm{Sr}_{2} \mathrm{MnO}_{2} \mathrm{Cu}_{2.5(2)} \mathrm{Li}_{0.6(2)} \mathrm{S}_{3}$, based on its position in the charge profile and because the NMR results suggest that some $\mathrm{Li}$ ions remains at this composition. This is the limiting composition assuming that no $\mathrm{Li}$ or $\mathrm{Cu}$ ions are present in the minority phase OS-III, so the OS-II phase also has at least one quarter of the tetrahedral metal sites in the sulfide layer vacant and is highly oxidized. Thus, we suggest that charge balance is 
achieved by residual $\mathrm{Li}$, and partial oxidation of $\mathrm{Cu}$ (above $1+$ ), S (above 2-), and $\mathrm{Mn}$ (given the number of variables, only the $\mathrm{Mn}$ oxidation state is used in Figure 13 for charge balance, i.e., the $\mathrm{Cu}$ is assumed to be all $\mathrm{Cu}^{1+}$ and thus $\mathrm{Mn}$ has an average oxidation state of 3.1). It is likely that the $\mathrm{Li}$ removal and only partial reinsertion of $\mathrm{Cu}$, resulting in a phase with an oxidation state of $\mathrm{Cu}$ beyond $1+$ and/or $\mathrm{Mn}$ above $2.5+$, result in the higher voltage of step $7(2.3 \mathrm{~V}$ from the GITT, Figure S1), in comparison to that of step $5(1.7 \mathrm{~V})$. The transition from the voltage associated with step 5 (which is also similar to that seen in the first discharge) to that of step 6 and then step 7 occurs when $\mathrm{Mn}$ has been oxidized to close to $\mathrm{Mn}^{2.5+}$ and $\mathrm{Cu}$ reinsertion cannot keep track with $\mathrm{Li}$ removal.

Discharging from the manganese oxysulfide OS-II and OSIII phases that are present at the end of the $2.3 \mathrm{~V}$ process purely involves reductive $\mathrm{Li}$ insertion into vacant sites in the sulfide layer (presumably in both the highly $\mathrm{Cu}$-deficient oxysulfide OS-II and the "collapsed" oxysulfide phase OS-III). This results in more capacity than seen for $(2.2 \mathrm{~V})$ step 1 in the discharge of the pristine phase, consistent with Li filling this large number of vacant sites with an accompanying reduction of $\mathrm{Mn}$ (and $\mathrm{Cu}$ ). Furthermore, the sample obtained at the end of the $2.2 \mathrm{~V}$ process during the second discharge indeed contains a similar amount of $\mathrm{Cu}$ to its precursor charged to $2.75 \mathrm{~V}(\mathrm{~g})$ (see Table 1), suggesting that extrusion of $\mathrm{Cu}$ is low until the lower voltage process commences. Hence, in the model proposed here, when the system is charged up to $2.75 \mathrm{~V}$, the $2.2 \mathrm{~V}$ process on discharge corresponds to pure $\mathrm{Li}$ intercalation/deintercalation into oxysulfide phases.

Upon charging from 2.75 to $3.75 \mathrm{~V}$ (step 8 ), the remaining $\mathrm{Li}$ is removed and further oxidation of largely all the $\mathrm{Cu}$ is clearly evident from the absence of crystalline elemental $\mathrm{Cu}$ upon charging to $3.75 \mathrm{~V}$ observed in the PXRD and NPD measurements although the $\mathrm{Cu}$ and $\mathrm{S}$ K-edge XANES measurements suggest that there are small differences between the pristine $\mathrm{Sr}_{2} \mathrm{MnO}_{2} \mathrm{Cu}_{3.5} \mathrm{~S}_{3}$ and the material obtained by charging up to $3.75 \mathrm{~V}$. It is clear that a notable amount of copper is only reinserted into the oxysulfide at these higher potentials. The overpotential required for reinsertion is ascribed to the high activation energy of $\mathrm{Cu}$ insertion (and lower mobility of the $\mathrm{Cu}^{+}$ion) than $\mathrm{Li}^{+}$migration so that the $\mathrm{Mn}$ ions are oxidized to their maximum stable oxidation state before $\mathrm{Cu}$ insertion. This has analogies with many conversion chemistries, where the sluggish TM (vs Li) migration results in a hysteresis between charge and discharge. ${ }^{42,43}$ A more closely related, so-called "path hysteresis" mechanism is seen for the Ti spinel $\mathrm{CuTi}_{2} \mathrm{~S}_{4}$, which undergoes a CDI reaction to form $\mathrm{LiTi}_{2} \mathrm{~S}_{4}+\mathrm{Cu}$ on discharging. The charge reaction then occurs at a higher voltage than the discharge voltage, the voltage being set by a different reaction, namely, the $\mathrm{Li}$ removal reaction to form $\mathrm{Ti}_{2} \mathrm{~S}_{4}{ }^{42}$ The different reactions on discharge and charge have been ascribed to the much lower mobility of the $\mathrm{Cu}^{1+}$ ions than $\mathrm{Li}^{+}$ions in the spinel structures. ${ }^{12,42} \mathrm{Cu}$ reinsertion in this system is partially accomplished via a chemical reaction. ${ }^{15}$

Overpotentials that will also induce $\mathrm{Cu}$ dissolution into the electrolyte are required to complete the reaction in the $\mathrm{Sr}_{2} \mathrm{MnO}_{2} \mathrm{Cu}_{3.5} \mathrm{~S}_{3}$ system. Although the diffraction data suggest that the composition $\mathrm{Sr}_{2} \mathrm{MnO}_{2} \mathrm{Cu}_{3.5} \mathrm{~S}_{3}$ is largely restored, the uncertainty in the refined composition $(\sim 0.2 \mathrm{Cu})$ does not rule out that some loss of $\mathrm{Cu}$ occurs due to this process of dissolution into the electrolyte during reinjection.
Upon subsequent discharge from this highly charged state, the electrochemical response mirrors that of the first discharge, contrary to what happens upon reduction from $2.75 \mathrm{~V}$. It is interesting to note that the capacity at $2.2 \mathrm{~V}$ at the start of the discharge process is twice as much in the second discharge as in the first, further supporting the existence of more $\mathrm{Cu}$ vacancies in the overcharged sample than in the pristine material and thus the possibility of $\mathrm{Cu}$ loss from the electrode material due to dissolution.

These results clearly indicate that the amount of $\mathrm{Cu}$ that needs to diffuse in and out of the active material particles is noticeably smaller when the cutoff voltage on charge is set at $2.75 \mathrm{~V}$. It is possible that cycling over smaller variations in $\mathrm{Cu}$ content will result in the introduction of less mechanical strain into the electrode, thereby providing a good explanation for the rather better cycling performance of $\mathrm{MnCu}$ (II) over the small voltage window than when cycled up to $3.75 \mathrm{~V}$. An additional source of capacity loss in the latter conditions relates to the dissolution of $\mathrm{Cu}$ ions. The evidence presented here strongly suggests that some of these ions are never reinjected into an oxysulfide. Thus, they can easily diffuse through the electrolyte over to the anode side, where they will be reduced by the very low potentials at which it operates. The result would be the plating of $\mathrm{Cu}$ onto the $\mathrm{Li}$ metal electrode used in the experiments and redox shuttle mechanisms.

\section{CONCLUSIONS}

Layered oxysulfides $\mathrm{Sr}_{2} \mathrm{MnO}_{2} \mathrm{Cu}_{2 m-\delta} \mathrm{S}_{m+1}(m=1,2$, and 3, $\delta \approx$ $0.5)$ with alternating perovskite-type $\left[\mathrm{Sr}_{2} \mathrm{MnO}_{2}\right]$ layers and antifluorite-type $\left[\mathrm{Cu}_{2} \mathrm{~S}\right]$ layers in the structure show reversible reactivity toward $\mathrm{Li}$ via a displacement mechanism. Measurements on the $m=2$ member made both during the electrochemical cycling and after stopping the cycling at various points reveal that the discharge proceeds both with $\mathrm{Mn}$ reduction in the oxide layer as well as by $\mathrm{Cu}$ reduction-cumextrusion from the sulfide layer.

Charging proceeds by a complex route in which initial $\mathrm{Li}$ deintercalation is compensated by $\mathrm{Mn}$ oxidation prior to the reinsertion of some $\mathrm{Cu}$. As charging continues, $\mathrm{Cu}$ insertion fails to fully compensate $\mathrm{Li}$ deintercalation, as far as $2.75 \mathrm{~V}$, resulting in manganese and copper oxidation and the formation of a new minority phase with a sharply contracted cell volume, which may be entirely devoid of cations in the sulfide layer and presents a target for bulk chemical synthesis.

The mechanisms of reactions upon discharge and charge are fundamentally different, involving not only different phases but also different oxidation states, resulting in a "path hysteresis" mechanism. The voltage asymmetry observed between discharge and charge during the first cycle can be explained by these differences. Charging to $3.75 \mathrm{~V}$ is required to effect almost complete $\mathrm{Cu}$ reinsertion and the restoration of a phase similar to $\mathrm{Sr}_{2} \mathrm{MnO}_{2} \mathrm{Cu}_{3.5} \mathrm{~S}_{3}$. The result is a second discharge profile that mirrors that of the discharge of the pristine material. This reinsertion most likely proceeds through dissolution of $\mathrm{Cu}$ into the electrolyte, with loss of these ions being a real possibility. The plating of these ions onto the negative electrode, together with the larger amounts of mass transport and reorganization involved in the cycling at $3.75 \mathrm{~V}$, is likely the culprit of the strong capacity loss observed upon cycling $\mathrm{MnCu}(\mathrm{II})$ over this extended voltage window. This work demonstrates the complexity of the displacement reactions in these layered oxysulfides, and the valuable information obtained in this study may provide further insight 
into other structurally related compounds, regarding their function in the lithium ion batteries.

\section{ASSOCIATED CONTENT}

\section{SI Supporting Information}

The Supporting Information is available free of charge at https://pubs.acs.org/doi/10.1021/acs.chemmater.1c00375.

The GITT result, cycling curve, Rietveld refinement plots of in situ XRD data, and $\mathrm{Cu}$ and $\mathrm{S}$ K-edge XANES spectra (PDF)

\section{AUTHOR INFORMATION}

\section{Corresponding Authors}

Simon J. Clarke - Department of Chemistry, University of Oxford, Oxford OX1 3QR, U.K.; (1) orcid.org/0000-00034599-8874; Email: simon.clarke@chem.ox.ac.uk

Clare P. Grey - Department of Chemistry, University of Cambridge, Cambridge CB2 1EW, U.K.; Department of Chemistry, State University of New York, Stony Brook, New York 11794-3400, United States; 이이.org/0000-00015572-192X; Email: cpg27@cam.ac.uk

\section{Authors}

Sunita Dey - Department of Chemistry, University of Cambridge, Cambridge CB2 1EW, U.K.; 이잉.org/00000002-6601-7169

Dongli Zeng - Department of Chemistry, State University of New York, Stony Brook, New York 11794-3400, United States

Paul Adamson - Department of Chemistry, University of Oxford, Oxford OX1 3QR, U.K.; (1) orcid.org/0000-00025873-0730

Jordi Cabana - Department of Chemistry, State University of New York, Stony Brook, New York 11794-3400, United States; Present Address: Present address: Department of Chemistry, University of Illinois at Chicago, Chicago, Illinois 60607, United States (J.C.).; 잉o․org/00000002-2353-5986

Sylvio Indris - Department of Chemistry, State University of New York, Stony Brook, New York 11794-3400, United States; Present Address: Present address: Institute for Applied Materials - Energy Storage Systems, Karlsruhe Institute of Technology, Hermann-von-Helmholtz-Platz 1, 76344 Eggenstein-Leopoldshafen, Germany (S.I).; (ㄱ) orcid.org/0000-0002-5100-113X

Jingyu Lu - Department of Chemistry, University of Cambridge, Cambridge CB2 1EW, U.K.; 이이.org/00000001-9777-9388

Complete contact information is available at: https://pubs.acs.org/10.1021/acs.chemmater.1c00375

\section{Author Contributions}

The manuscript was written through contributions of all authors. All authors have given approval to the final version of the manuscript.

\section{Notes}

The authors declare no competing financial interest.

\section{ACKNOWLEDGMENTS}

This work was supported as part of the Northeastern Center for Chemical Energy Storage (NECCES), an Energy Frontier Research Center funded by the U.S. Department of Energy,
Office of Science. We thank the UK EPSRC for a studentship for PA and for funding through grants EP/E025447/1 and EP/ P018874/1 and the UK STFC for access to the ISIS facility and Dr. R.I. Smith for assistance with NPD investigations. S.D. acknowledges DST Overseas Visiting Fellowship in Nano Science and Technology, Government of India (July 2018 to June 2019). J.L. acknowledges the funding from EPSRC grants EP/M009521/1 DJR00640 and EP/P003532/1. We also thank Dr. Anton Van der Ven from the University of Michigan for helpful discussions and making his work available before publication. The contribution to the work by JC was supported by Generalitat de Catalunya through a Beatriu de Pinós fellowship.

\section{REFERENCES}

(1) Cabana, J.; Monconduit, L.; Larcher, D.; Palacín, M. R. Beyond Intercalation-based Li-ion Batteries: The State of the Art and Challenges of Electrode Materials Reacting through Conversion Reactions. Adv. Mater. 2010, 22, E170-E192.

(2) Leroux, F.; Goward, G. R.; Power, W. P.; Nazar, L. F. Understanding the Nature of Low-Potential Li Uptake into High Volumetric Capacity Molybdenum Oxides. Electrochem. Solid-State Lett. 1999, 1, 255.

(3) Poizot, P.; Laruelle, S.; Grugeon, S.; Dupont, L.; Tarascon, J. M. Nano-Sized Transition-Metal Oxides as Negative-Electrode Materials for Lithium-Ion Batteries. Nature 2000, 407, 496-499.

(4) Amatucci, G. G.; Pereira, N. Fluoride Based Electrode Materials for Advanced Energy Storage Devices. J. Fluorine Chem. 2007, 128, 243-262.

(5) Malini, R.; Uma, U.; Sheela, T.; Ganesan, M.; Renganathan, N. G. Conversion reactions: a new pathway to realise energy in lithiumion battery-review. Ionics 2009, 15, 301-307.

(6) Kepler, K. D.; Vaughey, J. T.; Thackeray, M. M. Copper-Tin Anodes for Rechargeable Lithium Batteries: An Example of the Matrix Effect in an Intermetallic System. J. Power Sources 1999, 81-82, 383387.

(7) Thackeray, M. M.; Vaughey, J. T.; Johnson, C. S.; Kropf, A. J.; Benedek, R.; Fransson, L. M. L.; Edstrom, K. Structural Considerations of Intermetallic Electrodes for Lithium Batteries. J. Power Sources 2003, 113, 124-130.

(8) Kepler, K. D.; Vaughey, J. T.; Thackeray, M. M. $\mathrm{Li}_{x} \mathrm{Cu}_{6} \mathrm{Sn}_{5}$ $(0<x<13)$ : An Intermetallic Insertion Electrode for Rechargeable Lithium Batteries. Electrochem. Solid-State Lett. 1999, 2, 307.

(9) Leising, R. A.; Takeuchi, E. S. Solid-State Cathode Materials for Lithium Batteries: Effect of Synthesis Temperature on the Physical and Electrochemical Properties of Silver Vanadium Oxide. Chem. Mater. 1993, 5, 738-742.

(10) Morcrette, M.; Rozier, P.; Dupont, L.; Mugnier, E.; Sannier, L.; Galy, J.; Tarascon, J.-M. A Reversible Copper Extrusion-Insertion Electrode for Rechargeable Li Batteries. Nat. Mater. 2003, 2, 755761.

(11) Tarascon, J.-M.; Grugeon, S.; Morcrette, M.; Laruelle, S.; Rozier, P.; Poizot, P. New Concepts for the Search of Better Electrode Materials for Rechargeable Lithium Batteries. C. R. Chim. 2005, 8, 915 .

(12) Poizot, P.; Chevallier, F.; Laffont, L.; Morcrette, M.; Rozier, P.; Tarascon, J.-M. Evidence of an Electrochemically Assisted Ion Exchange Reaction in $\mathrm{Cu}_{2.33} \mathrm{~V}_{4} \mathrm{O}_{11}$ Electrode Material vs. Li. Electrochem. Solid-State Lett. 2005, 8, A184.

(13) Leising, R. A.; Thiebolt, W. C., III; Takeuchi, E. S. Solid-State Characterization of Reduced Silver Vanadium Oxide from the $\mathrm{Li}$ / SVO Discharge Reaction. Inorg. Chem. 1994, 33, 5733-5740.

(14) Leising, R. A.; Takeuchi, E. S. Solid-State Synthesis and Characterization of Silver Vanadium Oxide for Use as a Cathode Material for Lithium Batteries. Chem. Mater. 1994, 6, 489-495.

(15) Bodenez, V.; Dupont, L.; Morcrette, M.; Surcin, C.; Murphy, D. W.; Tarascon, J.-M. Copper Extrusion/Reinjection in Cu-Based 
Thiospinels by Electrochemical and Chemical Routes. Chem. Mater. 2006, 18, 4278-4287.

(16) Bodenez, V.; Dupont, L.; Laffont, L.; Armstrong, A. R.; Shaju, K. M.; Bruce, P. G.; Tarascon, J.-M. The Reaction of Lithium with $\mathrm{CuCr}_{2} \mathrm{~S}_{4}$-Lithium Intercalation and Copper Displacement/Extrusion. J. Mater. Chem. 2007, 17, 3238-3247.

(17) Rozier, P.; Morcrette, M.; Szajwaj, O.; Bodenez, V.; Dolle, M.; Surcin, C.; Dupont, L.; Tarascon, J. M. Li-Driven Copper Extrusion/ Re-injection in Various Cu-based Oxides and Sulfides. Isr. J. Chem. 2008, 48, 235-249.

(18) Sun, M.; Rousse, G.; Abakumov, A. M.; Saubanère, M.; Doublet, M.-L.; Rodríguez-Carvajal, J.; van Tendeloo, G.; Tarascon, J.-M. $\mathrm{Li}_{2} \mathrm{Cu}_{2} \mathrm{O}\left(\mathrm{SO}_{4}\right)_{2}$ : A Possible Electrode for Sustainable Li-Based Batteries Showing a 4.7 V Redox Activity vs $\mathrm{Li}^{+} / \mathrm{Li}^{0}$. Chem. Mater. 2015, 27, 3077-3087.

(19) Barrier, N.; Clarke, S. J. A Novel Layered Oxysulfide Intergrowth Compound $\mathrm{Sr}_{4} \mathrm{Mn}_{2} \mathrm{Cu}_{5} \mathrm{O}_{4} \mathrm{~S}_{5}$ Containing a Fragment of the $\alpha-\mathrm{Cu}_{2} \mathrm{~S}$ Antifluorite Structure. Chem. Commun. 2003, 1, 164-165.

(20) Gál, Z. A.; Rutt, O. J.; Smura, C. F.; Overton, T. P.; Barrier, N.; Clarke, S. J.; Hadermann, J. Structural Chemistry and Metamagnetism of an Homologous Series of Layered Manganese Oxysulfides. J. Am. Chem. Soc. 2006, 128, 8530-8540.

(21) Rutt, O. J.; Williams, G. R.; Clarke, S. J. Reversible Lithium Insertion and Copper Extrusion in Layered Oxysulfides. Chem. Commun. 2006, 27, 2869-2871.

(22) Indris, S.; Cabana, J.; Rutt, O. J.; Clarke, S. J.; Grey, C. P. Layered Oxysulfides $\mathrm{Sr}_{2} \mathrm{MnO}_{2} \mathrm{Cu}_{2 m-0.5} \mathrm{~S}_{m+1}(\mathrm{~m}=1,2$, and 3$)$ as Insertion Hosts for $\mathrm{Li}$ Ion Batteries. J. Am. Chem. Soc. 2006, 128, 13354-13355.

(23) Indris, S.; Zeng, D.; Cabana, J.; Smura, C. F.; Rutt, O. J.; Clarke, S. J.; Grey, C. P. Electrochemical Insertion of $\mathrm{Li}$ into $\mathrm{Sr}_{2} \mathrm{MO}_{2} \mathrm{Cu}_{2} \mathrm{~S}_{2}(\mathrm{~m}=\mathrm{Mn}, \mathrm{Co}, \mathrm{Ni})$. MRS Proc. 2006, 988, No. 0988QQ08-08.

(24) Robert, R.; Zeng, D.; Lanzirotti, A.; Adamson, P.; Clarke, S. J.; Grey, C. P. Scanning X-Ray Fluorescence Imaging Study of Lithium Insertion into Copper Based Oxysulfides for Li-Ion Batteries. Chem. Mater. 2012, 24, 2684-2691.

(25) Smura, C. F.; Parker, D. R.; Zbiri, M.; Johnson, M. R.; Gál, Z. A.; Clarke, S. J. High-Spin Cobalt(II) Ions in Square Planar Coordination: Structures and Magnetism of the Oxysulfides $\mathrm{Sr}_{2} \mathrm{CoO}_{2} \mathrm{Cu}_{2} \mathrm{~S}_{2}$ and $\mathrm{Ba}_{2} \mathrm{CoO}_{2} \mathrm{Cu}_{2} \mathrm{~S}_{2}$ and Their Solid Solution. J. Am. Chem. Soc. 2011, 133, 2691-2705.

(26) Clarke, S. J.; Adamson, P.; Herkelrath, S. J. C.; Rutt, O. J.; Parker, D. R.; Pitcher, M. J.; Smura, C. F. Structures, Physical Properties, and Chemistry of Layered Oxychalcogenides and Oxypnictides. Inorg. Chem. 2008, 47, 8473-8486.

(27) Dey, S.; Lee, J.; Britto, S.; Stratford, J. M.; Keyzer, E. N.; Dunstan, M. T.; Cibin, G.; Cassidy, S. J.; Elgaml, M.; Grey, C. P. Exploring Cation-Anion Redox Processes in One-Dimensional Linear Chain Vanadium Tetrasulfide Rechargeable Magnesium Ion Cathodes. J. Am. Chem. Soc. 2020, 142, 19588-19601.

(28) Britto, S.; Leskes, M.; Hua, X.; Hébert, C.-A.; Shin, H. S.; Clarke, S.; Borkiewicz, O.; Chapman, K. W.; Seshadri, R.; Cho, J.; Grey, C. P. Multiple Redox Modes in the Reversible Lithiation of High-Capacity, Peierls-Distorted Vanadium Sulfide. J. Am. Chem. Soc. 2015, 137, 8499-8508.

(29) Hansen, C.; Zak, J.; Martinolich, A.; Ko, J.; Bashian, N.; Kaboudvand, F.; van der Ven, A.; Melot, B.; Nelson Weker, J.; See, K. Multielectron, Cation and Anion Redox in Lithium-Rich Iron Sulfide Cathodes. J. Am. Chem. Soc. 2020, 142, 6737-6749.

(30) Morcrette, M.; Chabre, Y.; Vaughan, G.; Amatucci, G.; Leriche, J.-B.; Patoux, S.; Masquelier, C.; Tarascon, J. M. In Situ X-Ray Diffraction Techniques as a Powerful Tool to Study Battery Electrode Materials. Electrochim. Acta 2002, 47, 3137-3149.

(31) Larson, A. C.; Von Dreele, R. B. General Structure Analysis System(GSAS); Los Alamos Natl Lab, Rep. LAUR: 1994, 86-748.

(32) Toby, B. H. EXPGUI, a Graphical User Interface for GSAS. J. Appl. Crystallogr. 2001, 34, 210-213.
(33) Chung, J.-S.; Sohn, H.-J. Electrochemical Behaviors of CuS as a Cathode Material for Lithium Secondary Batteries. J. Power Sources 2002, 108, 226-231.

(34) Yamakawa, N.; Jiang, M.; Grey, C. P. Investigation of the Conversion Reaction Mechanisms for Binary Copper (II) Compounds by Solid-State NMR Spectroscopy and X-Ray Diffraction. Chem. Mater. 2009, 21, 3162-3176.

(35) Galus, Z.; Bard, A.; Parsons, R.; Jordan, J. Standard Potentials in Aqueous Solution; by A. J., Bard; R., Parsons; J., Jordan, IUPAC, Marcel Dekker, Inc., New York 1985, 200-206.

(36) Wu, Z. Y.; Ouvrard, G.; Lemaux, S.; Moreau, P.; Gressier, P.; Lemoigno, F.; Rouxel, J. Sulfur K-Edge X-Ray-Absorption Study of the Charge Transfer upon Lithium Intercalation into Titanium Disulfide. Phys. Rev. Lett. 1996, 77, 2101-2104.

(37) Li, D.; Bancroft, G. M.; Kasrai, M.; Fleet, M. E.; Feng, X. H.; Yang, B. X.; Tan, K. H. S K-and L-Edge XANES and Electronic Structure of Some Copper Sulfide Minerals. Phys. Chem. Miner. 1994, 21, 317-324.

(38) Wang, T.; Ren, G.-X.; Shadike, Z.; Yue, J.-L.; Cao, M.-H.; Zhang, J.-N.; Chen, M.-W.; Yang, X.-Q.; Bak, S.-M.; Northrup, P.; Liu, P.; Liu, X.-S.; Fu, Z.-W. Anionic Redox Reaction in Layered $\mathrm{NaCr}_{2 / 3} \mathrm{Ti}_{1 / 3} \mathrm{~S}_{2}$ through Electron Holes Formation and Dimerization of S-S. Nat. Commun. 2019, 10, 4458.

(39) Totir, D. A.; Antonio, M. R.; Schilling, P.; Tittsworth, R.; Scherson, D. A. In Situ Sulfur K-Edge X-Ray Absorption near Edge Structure of an Embedded Pyrite Particle Electrode in a Non-Aqueous $\mathrm{Li}^{+}$-Based Electrolyte Solution. Electrochim. Acta 2002, 47, 31953200.

(40) Lee, Y. J.; Wang, F.; Grey, C. P. ${ }^{6} \mathrm{Li}$ and ${ }^{7} \mathrm{Li}$ MAS NMR Studies of Lithium Manganate Cathode Materials. J. Am. Chem. Soc. 1998, 120, 12601-12613.

(41) Vajenine, G. V.; Hoffmann, R. Compounds Containing Copper- Sulfur Layers: Electronic Structure, Conductivity, and Stability. Inorg. Chem. 1996, 35, 451-457.

(42) Chang, D.; Chen, M.-H.; Van der Ven, A. Factors Contributing to Path Hysteresis of Displacement and Conversion Reactions in $\mathrm{Li}$ Ion Batteries. Chem. Mater. 2015, 27, 7593-7600.

(43) Doe, R. E.; Persson, K. A.; Meng, Y. S.; Ceder, G. FirstPrinciples Investigation of the $\mathrm{Li}-\mathrm{Fe}-\mathrm{F}$ Phase Diagram and Equilibrium and Nonequilibrium Conversion Reactions of Iron Fluorides with Lithium. Chem. Mater. 2008, 20, 5274-5283. 